\title{
The Growth and Regeneration of the Tail of the Frog Larva.
}

Studied with the Aid of Born's Method of Grafting.

By

Ross Granville Harrison,

Associate in Anatomy, Johns Hopkins University, Baltimore, U.S. A.

With Plates X-XI and 21 Figures in text.

Eingegangen am 1. Juli 1898.

In the method of grafting we have a means of experimentation for which no substitute is offered. Bons's discovery that certain amphibian embryos lend themselves with readiness to such operations, is of especial importance in that it renders the method applicable to the study of developmental problems. How important this form of experiment is, may be well appreciated from a careful study of the paper in which BonN records the results of his work in this field.

In the spring of 1897 I instituted a number of experiments according to BoRs's method upon the embryos of several of our American frogs, which were found to be well adapted to the purpose. An account of these experiments is here given.

The embryos of two of the forms used differ so markedly in coloration, that in any case where parts derived from each are united together into a single organism one may follow in the living specimen, as development proceeds, the movement of any group or layer of cells with respect to the original dividing line between the two constituents. By varying the region in which the parts are stuck together it thus becomes possible to trace out the mode of growth of individual structures or organs.

These circumstances were taken advantage of in a series of experiments which are described here in the second section. They 
concern more especially the normal mode of growth of the tail from the time when the medullary folds are closed over and the tail bud is just formed; they form therefore the basis for the study of the later phases of development, beginning with the stage at which nearly all previous accounts leave off. During the development of the tail a remarkable shifting of the epidermis over the underlying organs was observed to take place. This was followed in some detail since it is of importance in explaining the mode of distribution of cutaneous nerves in the adult.

Another series of experiments, referring to the regeneration of the tail, was made with the special object in view of ascertaining to what extent the oral end or pole of the amputated tail rudiment is capable of regenerating. These are described in the third and fourth sections.

Finally in the fifth section some seattered observations upon the fate of the tissues in the heteroplastic combinations are recorded.

The matter is thus considered under the following headings:

I. Material and Methods.

II. The Growth of the Tail and its Bearing upon the Mode of Distribution of Cutaneous Nerves.

III. The Regeneration of the Tail.

IV. The Regeneration of the Reversed Tail.

V. Reactions between Tissues Derived from Different Species.

\section{Material and Methods.}

In the vicinity of Baltimore the spawn of various amphibia may be obtained in great abundance. For the purpose of experiment I made use of the embryos of Amblystoma punctatum, and of several species of frog, including Rana sylvatica, R. virescens (halecina), and R. palustris. The embryos of Amblystoma, however, are not at all adapted for transplantation experiments for the reason that their wound-healing power is but very slight. Since the yolk oozes out when laid bare instead of being quickly covered again by the overgrowth of the ectoderm, the whole embryo eventually macerates in consequence even of simple operations ${ }^{1}$ ).

Of the three anouran species used all possess that power of rapid wound-healing which is the chief essential to successful grafting.

1) BoRN had the same difficulty with Triton embryos. 
For the present purpose the most fortunate combination between two species is that of $R$. palustris and $R$. virescens, on account of the very sharp color contrast, and the absence of undue difference in size between them. The eggs and embryos of the former are of a light yellowish brown color, while those of the latter are dark brown, almost black. The coloration is due partly to the embryonic pigment situated for the most part in the ectoderm cells, and partly to the yolk granules, which are scattered throughout all the tissues. In R. palustris the latter are of a decided yellowish hue, while in R. virescens they are light drab or almost white. The contrast between the two species is sharpest in the cells of the epidermis. In any combination of embryos of the two forms it is possible to distinguish in this layer the species from which every single cell is derived. In the structures underlying the epidermis the sharpness of the contrast is somewhat obscured (especially for the first day or two after union) by the imperfect transparency of the tissues. But even in the endoderm or in the axial musculature the specific coloration of the cells may be clearly made out. The distinguishing characters persist for ten days or more after grafting, and during this period many important developmental changes take place. After the expiration of this time the absorption of the yolk granules and the disappearance of the embryonic pigment from the epidermis cells make it more difficult to distinguish between cells of the two species. The perceptible differences between the two then no longer extend to each individual cell. This is true with regard to color differences, upon the existence of which the method is largely dependent, for the specific markings of older larvae are due to the characteristic groupings of the large mesenchymal chromatophores, rather than to differences in their individual form and color.

The embryos which were made use of in all the grafting experiments were in that stage of development in which the medullary folds are entirely closed over, and the tail bud is well rounded off from the trunk (Fig. 2) ${ }^{1}$ ). In this stage the embryos of R. virescens are about $4 \mathrm{~mm}$ in length, while those of $R$. palustris are slightly longer.

The spawning period of $R$. virescens is short. In the spring of 1897 it lasted but about ten days (March $22^{\text {nd }}$ to April $1^{\text {st }}$ ). The first

1) This is perhaps a slightly older stage than that which BoRN found to be most advantageous. 
eggs of $R$. palustris were found on April $1^{\text {st }}$. For this reason it was necessary to resort to ice for the purpose of arresting development and prolonging the season during which grafting experiments conld be carried on. The egrgs were kept at a temperature just a little above freezing point of water without undergoing deterioration. They made but little perceptible advance in development during the five weeks they were retained.

Concerning the methods employed in transplantation, there is but little to add here to BonN's account. In but one essential did the method pursued in the present research differ from his. That is, cool tap water was used instead of salt solution, as the medium in which the operations were performed. The former has two distinct advantages over the latter. In the first place it obviates the necessity of bringing the larvae back to their normal medium after operation and healing in salt solution. This, according to Bons's experience, must be done very gradually and is a rather tedious process. The second and more weighty objection to the use of salt, is that the larvae show the effect of their treatment both in retardation of development and in general weakness ${ }^{1}$ ). It is true that a larger proportion of experiments are successful initially when the operation is performed in salt solution, in which the wounds heal more quickly and surely. But the much larger percentage of healthy and vigorous tadpoles which survive in the end, when only cool-fresh water is used, more than compensates for the cases unsuccessful at the start. Nevertheless in any case, one must expect to lose many promising composite individuals, and very often as BoRN points out, from causes apparently unassignable.

The method of study consisted largely in the daily observation upon the living specimen, although a quantity of material was preserved for histological investigation. The figures in the text (exept Figs. 1, 14 and 18) are all reproduced from ontline drawings of the living tadpoles made with the camera lucida. One experiences considerable difficulty in sketching the larvae by means of the camera, for it is almost impossible to keep them perfectly still. Care was taken, however, that the important parts (in most cases the tail)

1) Bons mentions that operations of less difficult nature may be successfully performed in water. He also calls attention to the ill effects of keeping: the larvae too long in salt solution. For a special stady of the influence of salt solution upon the development of amphibia, which was first noted by Morgan (18), see Hertwig (10) and Wilson (28). 
should be made perfectly accurate. In some cases the body and head were afterwards drawn in from preserved specimens.

The photographs reproduced in Plate $X$ were made from the living tadpoles. Those of the four frogs (Pl. XI) were taken from specimens preserved in formaldehyde. For the purpose of photographing live tadpoles the apparatus, originally intended for photomicrography, was arranged as shown in the diagram (Fig. 1) ${ }^{1}$ ). The larvae were put into a glass cell $(a)$ having vertical plane walls and filled with water. This was placed directly between the camera $(c)$ and the source of the light $(l)$; an are light of four thousand candle power. This could be so adjusted by screwing from side to

Fig. 1.

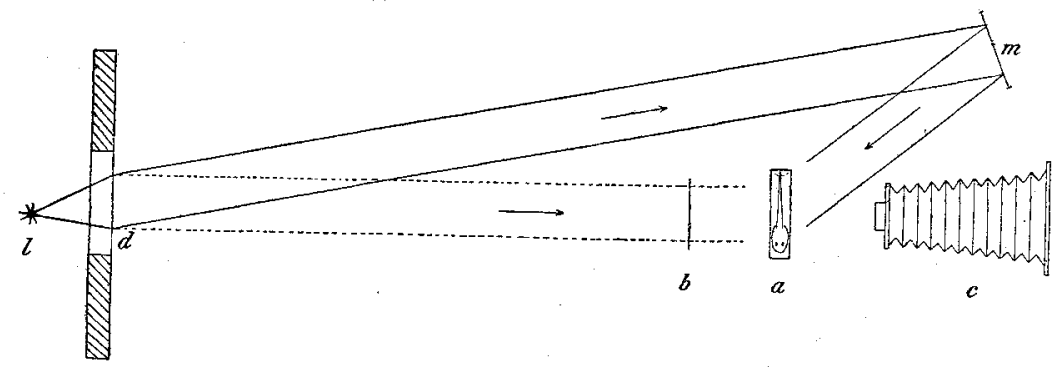

Diagram showing method of illumination used in photographing living tadpoles. Explanation in text.

side, that the rays, made parallel by passing through the condenser $(d)$, were directed so as to pass somewhat obliquely to one side of the water chamber, to the surface of a plane mirror $(m)$, which was placed so as to reflect the light to the surface of the tadpole turned towards the camera. At the same time a small amount of diffuse light passed through the glass cell and likewise through the tail of the larva. The strong reflected light was to bring out the surface markings, while the transmitted light gave a transparent effect to the tail. Naturally, a great deal of experimentation was necessary before the proper proportions of reflected and transmitted light could be determined. The difficulty was increased by the fact that this proportion is different for each tadpole, since it depends upon the deepness of pigmentation. The intensity of the reflected light was found to be best left at its maximum, while that of the transmitted, could be most conveniently regulated by the interposition of colored

1) This apparatus has been described in full by HoEN (11). 
screens $(b)$ of different actinic power. Exposure of sèveral seconds upon very sensitive plates was necessary to bring out surface markings properly. This accounts for the blurred appearance of the mouth parts in the majority of the figures ${ }^{1}$ ). Unfortunately many of the details shown in the original photographs have been lost in the process of reproduction.

\section{The Growth of the Tail and its Bearing upon the Mode of Distribution of Cutaneous Nerves.}

It is the generally accepted view that the tail of the vertebrate embryo increases in length by a process of apical growth. There is no doubt that the new muscle plates are added at the tip, and it is here that the notochord and spinal cord remain undifferentiated and contain numerous cells in process of division as evidence of active growth.

In the method of combining parts of differently pigmented embryos we have a means of testing whether the accepted view is correct as regards each of the individual constituents of the tail. For this purpose the following experiment may be made: The tail of an embryo of $R$. palustris is eut off and transplanted to the body of a virescens embryo in place of its own tail, which has previously Fig. 2.

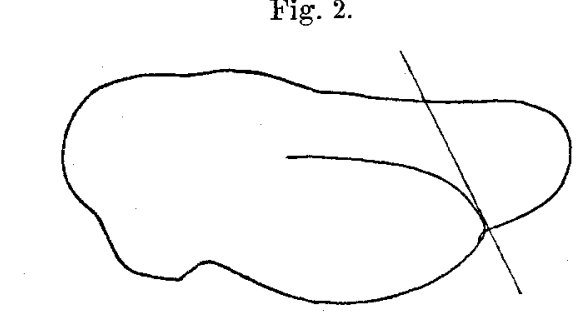

Rana virescens in grafting stage, showing cut made when tail alone is to be replaced. $>11$. been removed. The cut is best made in an oblique direction with respect to the axis of the body in a line passing just distal to the anus (Fig. 2)2). The wound heals very readily after this light operation, but owing to the sharp contrast in color between the tissues of the two species the transplanted tail may be distinguished from the body even by the naked eye.

I give below the history of an individual case, the one from which the figures were made.

1) It gives me great pleasure to express here my obligation to Mr. A. S. MURRAY for much invaluable aid given in connection with the work of photography.

2) The oblique cut is preferable to the transverse in that it affords an easy means of distinguishing the dorsal edge of the small piece from the ventral. 
On the day after the operation the epidermis of the trunk (R. virescens) extends out over the base of the tail (R. palustris). The light ectoderm (stippled area, Fig. 3) of the grafted tail has increased in extent as compared with the day before, but not commensurately with the increase in length of the tail, which is now considerably longer than at the time of operation. Two days after a still larger

Fig. 3.

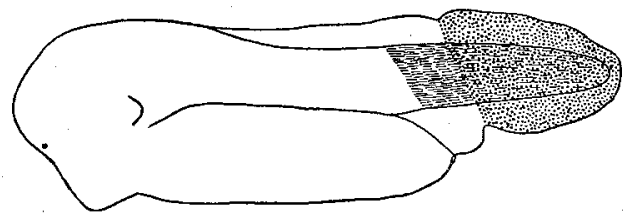

Same larva as in Fig. 2, thirty hours after operation. Virescens tissue simply outlined; palustris epidermis stippled; palustris musculature shaded. $\times 11$.

portion of the base of the tail is covered by the same epidermis as the body, so that at this time but little over half of the tail is covered over by the transplanted epidermis (Fig. 4). On the fourth day, the length of the tail having continued to increase, the area of light brown ectoderm becomes still further removed from the base. The line of demarcation still retains its oblique direction in a general way, but is becoming wavy or jagged, and is as a whole somewhat curved where it passes over the axis of the tail, the convexity being

Fig. 4.

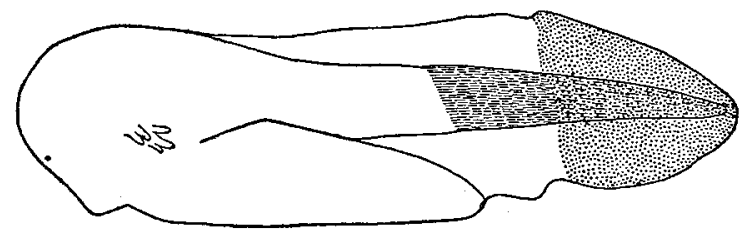

Same larva, fifty-three hours after operation. $>11$.

turned towards the distal end (Fig. 5). This is noticeable in all cases, though in a varying degree. On each following day the ectoderm of the trunk moves further and further out over the tail, the boundary between the two kinds of epidermis becoming more irregular and jagged (Fig. 6). The epidermal cells of the body do not cover up or replace those of the tail, however, for the surface covered by the latter continues to inerease in absolute amount. By the eighth day or, in some cases, earlier, nearly two-thirds of the 
tail is covered by cells which has shifted to it from the body (Fig. 7). After the expiration of this time there is only a slight further change in the position of the line of demarcation. It may be made out in some cases for a week longer. Then, owing to the disappearance of yolk granules and of pigment from the epidermis cells, it becomes practically impossible to distinguish between the cells of the two species.

Fig. 5.

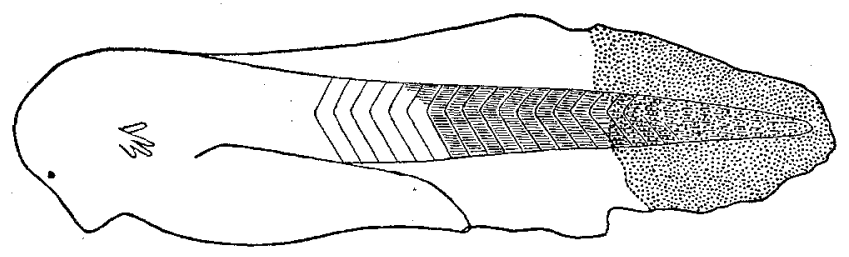

Same larva, seventy-seven bours after operation. $\times 11$.

In all, twenty cases were observed and without exception the changes just described took place, and in exactly the same manner in the reciprocal experiment where a virescens tail was grafted to the body of a palustris embryo. In a number of cases the tails of two larvae were merely interchanged, so that an exact comparison could be instituted.

Fig. 6.

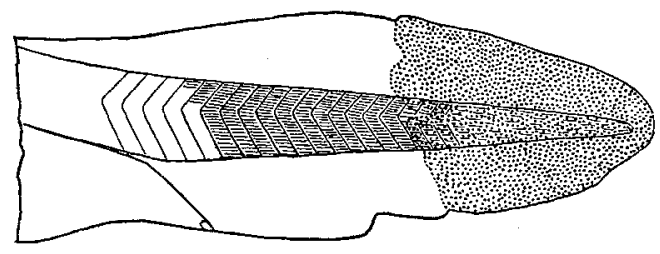

Tail half of same larva, five days after operation. $>11$.

The changes in position of the boundary between the integument of the two components is due beyond a donbt to actual shifting of the cells and not to any mere diffusion of pigment granules. This may be clearly demonstrated by examining the border under moderate magnifying power with strong reflected light. This brings into view the individual cells. Those of each component maintain absolutely their specific coloring without there being any intermingling of pigment granules whatever. The boundary line is a zigzag one, the two kinds of cells being neatly fitted to one another ${ }^{l}$ ).

1) The shifting of the epidermis may likewise be demonstrated by following 
With regard to the structures underlying the epidermis the changes of relative position which take place during growth are not so marked as. in the epidermis itself. On the day after the operation the larva is still very opaque, but even then, with proper illumination, something of the deep lying tissues, more especially the muscle plates, may be made out. The line of demarcation between the muscle tissue of the virescens constituent (outlined in the figures) and the that of the palustris tail (shaded in the figures) is seen to have remained at the base of the tail, very near to where it was just after the operation, while the epidermis of the body has crept some distance out beyond its original territory (Fig. 3). Three days

Fig. 7 .

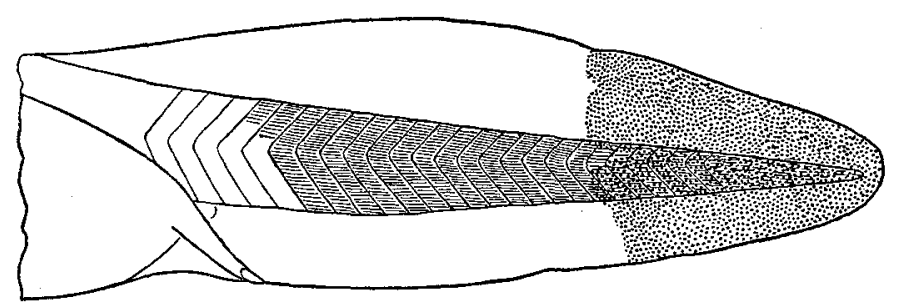

Tail half of same larva, seven days after operation. $\times 14$.

after the operation the individual muscle plates may be observed. The oblique cut made in operating has evidently affected several segments, for at least two of them are made up partly from each component. These two are nevertheless perfect in form (Fig. 5). During the three days the position of the junction between the two parts has moved slightly away from the head as compared with the position of the anus, regarded as a fixed point. This relative movement continues slowly (Fig. 6) until about the eighth day it amounts approximately to the length of three segments. The point of union, as seen on the rentral edge of the muscle plates is now considerably distal to the anus (Fig. 7), while a perpendicular drawn through the anus at this stage strikes the posterior part of the eleventh segment (counting from the head) instead of the fourteenth as at the time of operating. This change of position is due to the relative increase in the length of the individual muscle plates as

the movement of a scar during development. ByRnes (4) found that scars made in the region of the hind legs in embryos in the stage shown in Fig. 2 gradually pass out towards the tip of the tail. 
compared with the length of the body (from nose to anus), which latter, as may be seen from the comparison of the sketches (Fig. 2 $-5)$, expands but slowly. Measurements made from sections of larvae preserved in stages corresponding to those shown in Fig. 2 and Fig. 7 demonstrate that the average length of the myotomes increases during this time about seventy per cent of the original length, while the distance from the pituitary body to the anus (projected upon the notochord) increases but about forty per cent. This shows that differences in amount of interstitial growth will account for the relative change of position. Besides, as is well known, intercalation of myotomes during development and additions to the series from the cranial end have not been observed to take place. The shifting of the muscle plates out from the trunk to the base of the tail is accentuated in appearance by the increase in breadth of the fin fold, by which the anal opening is removed to a considerable distance ventral to the limit of the muscle plates.

The growth of the notochord apparently keeps pace with that of the series of myotomes, and is due, as is well known, largely to apical growth. Further evidence of this is to be had from these experiments, for in grafting it is very seldom that the tissues of the notochord of the two components actually fuse together. They remain separated by connective tissue; the blunt ends when they abut against one another bend slightly to one side ${ }^{1}$. During the growth of these transplanted tails it is in the distal piece of chorda that by far the greatest amount of increase in length takes place. The point of union of the two parts of the chorda dorsalis remains by the junction between the myotomes of the two components. The relative amount of interstitial and of apical growth is therefore the same in both notochord and axial musculature.

Regarding the growth of the spinal cord the present experiments do not adduce new evidence. Its tip keeps up with the tip of the notochord as the tail grows. There is such complete union of the two portions of spinal cord in the healing of the wound after grafting that no scar remains as a landmark. That the greater amount of growth takes place from the end is, however, certain from the well known fact that the interstitial growth does not keep pace with that of the vertebral column and segmental musculature, the circumstance which leads to the formation of the cauda equina.

1) ef. pag. 463. Also BonN, 1. c. pag. 394.

Archiv f. Entwickelungsmechanik. VII. 
The shifting of the epidermis tailwards over the underlying organs is not confined merely to the tail, as further investigation shows. In another series of experiments, instead of grafting only the tail to the body of another larva, a small portion of the trunk, say about four segments, including a portion of the yolk mass, was transplanted to the body of a larva of the other species, from which

Fig. 8.

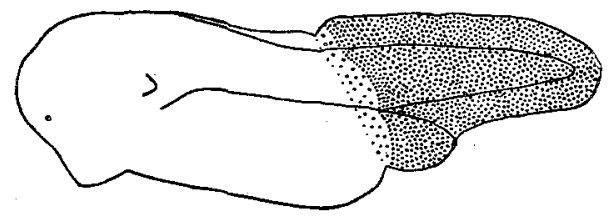

Rana virescens with tail and small portion of trunk replaced by palustris tissue, twenty-six hours after operation. Palustris epidermis densely stippled; palustris yolk and mesoderm covered by virescens epidermis lightiy stippled. $>11$.

the same amount had been cut off. In such cases on the day after the operation the epidermis of the body has moved slightly towards the tail over the underlying tissues of the other component (Fig. 8) ${ }^{1}$ ).

Four days after the operation the amount of shifting is so considerable that even the base of the tail is covered with the

Fig. 9.

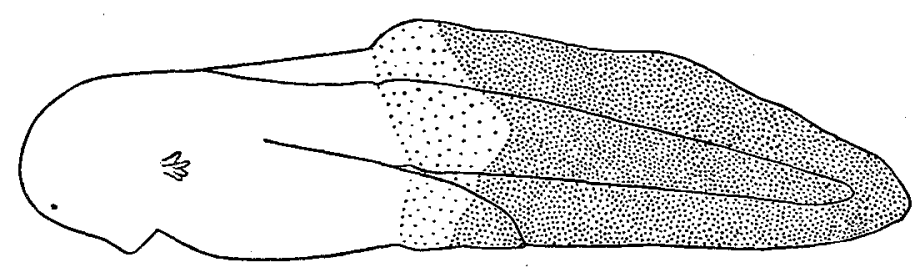

Same as Fig. 8, four days after operation. $\times 11$.

dark skin. The line of demareation (between lightly and heavily stippled areas in the figures), originally straight, now takes a very characteristic sharp bend at the level of the middle of the muscle plates, so that while the dorsal portion passes ventrally and tailwards, the ventral portion has a ventral and cranial direction (Fig. 9). The

1) For a day or two after the operation in such cases a very marked constriction where the two portions of yolk join may be observed. This disappears entirely in the course of time and the composite larva assumes a normal appearance. 
skin of the dorsal half has moved further than that of the ventral. It seems probable that the movement is held in check ventrally by the opening of the alimentary tract, where the epidermal cells are continuous with the cells lining the cloaca. In the underlying organs some changes have also occurred. The muscle plates of the posterior component are pushed further towards the tail as compared with the yolk. The limit between the muscle tissue of the two parts retains its original direction, but between the two kinds of yolk this is not the case, for here the boundary is either nearly perpendicular or runs ventrally and headwards. The shifting of the epidermis continues until the integument of the anterior component extends to a point just beyond the anus ventrally, while dorsally a considerable stretch of the tail is covered by it. In amount, the movement is considerably less in this region than furher towards the tip of the tail, as demonstrated in the first series of experiments.

Even in the region of the pronephros and forelimb there is a slight change in position of the ectoderm with respect to the underlying organs as development proceeds. This is clearly shown in specimens in which the two constituents are united in this region. After the expiration of a week the position of the border between the two kinds of skin may be observed to have shifted somewhat in the same direction as in the posterior part of the trunk and tail, though relatively much less in amount.

The explanation of this general movement of the epidermis from the head towards the tail is to be sought in the absence from this tissue of any definite growing point such as is found at the tip of the axial organs of the tail. At least, if there is a greater proliferation of cells in the epidermis of the tip than elsewhere over the body, it is not sufficient to keep pace with the general increase in length. A glance at the figures used in the foregoing description shows that during the one week in which this shifting takes place, the tail grows from almost nothing to a length greater than that of the rest of the animal (cf. Fig. 2, 5 and 7). The consequence of this rapid growth is a steady pulling of the covering of the body out to the tail, since the attachment of the epidermis to the underlying tissues must offer but insufficient resistance to this movement. The greatest amount of shifting is found in the cells nearest to the tip, and it becomes less and less as the head is approached. A given cell located originally at the posterior limit of the fourteenth myotome moves during seven days to a point at least $2,5 \mathrm{~mm}$ further peripherally, that is, through 
a distance equal to about fourteen segments. Of course it is probable that a certain amount of the movement is due to the protoplasmic activities of the ectoderm cells themselves, as we have good evidence of the amoeboid activity of such cells, especially in the covering of wounds, and in fact when the tail is amputated ${ }^{1}$ ).

To sum up then: The tail of the tadpole increases in length by a process of apical growth in the musculature, notochord and spinal cord, and also, but to a much less extent, by the greater amount of interstitial growth of these parts as compared with that of the body as a whole; this latter factor results in the pushing of about three segments from the body to the base of the tail. Little or no evidence of apical growth is to be found in the epidermis, which gradually moves out from the body to the tail, so that finally twothirds of the latter becomes covered by skin from the body ${ }^{2}$.

The gliding of the skin over the underlying organs is a most interesting phenomenon when considered in connexion with the mode of distribution of the cutaneons nerves in the adult vertebrate.

As is well known, the integument of the trunk is divisible into a series of zones, each of which corresponds to the area of distribution of a given spinal nerve. There is an overlapping of adjacent zones, but the sensory areas of the individual nerves are continnous, at least in those portions of the trunk left undisturbed by the growth of the extremities. The portion of the skin innervated by a given spinal nerve does not necessarily exactly overlie the muscular zone which is supplied by the ventral root of the same nerve. In the region of the first dorsal vertebra the limits of the sensory and motor belts do correspond very nearly, but on passing towards the tail the discrepancy between the two increases. The sensory area lies relatively further tailwards than the corresponding muscles $\left.{ }^{3}\right)$. The cutaneous

1) The covering of wounds through the amoeboid activity of epidermis cells was first demonstrated by Pexers (20) in the case of the frog's cornea. BARFURTH (2) confirmed this result in his study of wound-healing after amputation of the tail.

2) This supports H. VIRCHow's (23) conclusion drawn from the study of the formation of the tail in Elasmobranchs.

3) This has been shown physiologically most recently by SHERRINGToN (22) who has worked the matter out especially carefully on the monkey, Macacus, giving a full account of previous work upon the subject. Unfortunately, in the frog his study was confined to the hind limbs alone and did not include the trunk. In man the sensory areas have been very completely defined clinically by HEAD (7) whose diagrams show very clearly the increasing discrepancy 
nerves in passing to the skin take a more and more oblique direction the further tailwards their origin 1). In the tadpole those nerves which run to the tip of the tail arise not far from its base and pass nearly longitudinally to their destination.

The shifting of the epidermis during development over the subjacent muscle plates, as ascertained above experimentally, corresponds in direction and in relative amount in the different regions with the displacement of the sensory area as compared with the motor belt of the same segmental nerve. In the region of the upper dorsal vertebrae there is but little shifting and but a slight segmental discrepancy between sensory and motor zones, while both increase gradually as the tail is approached ${ }^{2}$ ).

Wandering of skin, then, like wandering of muscles, occurs during development, but the nerves remain to indicate the course of this ontogenetic wandering of the one as well as of the other.

These considerations suggest that a connection between each ganglion cell and its end organs in the integument is established early in development, and that each nerve rudiment in its first stage passes from its origin in the ganglion cell by the shortest path to the integument; and conversely, that each portion of the integument in this stage is innervated by that nerve the root of which has its origin nearest to it. The more complicated relations found in the adult are due to the gradual drawing out of these connecting nerves, as the parts separate during development ${ }^{3}$ ).

between the level of the exit of the nerve from the vertebral canal and its area of distribution in the skin, as the sacral region is approached. As SHERRINGTON points out there is more than a general correspondence between his own results and those of Head.

1) This is independent of the oblique course taken by the nerves in passing from the origin in the cord to those points of exit from the vertebral canal, which is accounted for by the unequal growth of the spinal cord and vertebral columa.

2) When the position of the sensory area is compared with the point of origin of the nerve from the spinal cord, the segmental difference between the two becomes even more marked. And this difference affords a much more exact measure of the amount of shifting of the skin, since, as shown above, the muscle plates shift considerably in the same direction during development.

3) This conclusion is identical in part with the well known view of Hensen (8, pag. 121), »dass die Nerven nicht ins Gewebe hineinwachsen, sondern durch die allmähliche Entfernung der einzelnen Zellen und Gewebe von einander a usgezogen wiirden . But it cannot be said to lend positive: support to the opinion expressed less reservedly in a later paper (HENSEN, 9, 
There is indication that in each region where there is discrepancy between sensory and motor zones, the cause of the shifting is to be sought in the actual pulling of the skin, which results from the unequal growth of subjacent structures in the embryo. Thus, in man the rapid growth of the hind limbs would have the same effect as that of the tail of the tadpole in pulling the skin from above. Likewise, it does not seem improbable that the great increase in the size of the brain may account in the same way for the distribution of cervical nerves to the occipital region.

Of course it is meant to explain in this way only the course of the main nerves and not the finer anastomoses, and it is not intended to deny that other factors than the shifting ${ }^{-}$of the skin play a part in determining the course taken by its nerves in the adult. For instance, this must certainly be the case with the lateral branch of the vagus; for the sense organs of the lateral line in the grafted larvae just described form a complete series extending to the extreme tip of the tail and continuing without break or bend from the integument of one component to that of the other, although, as can be directly observed, all of them receive fibres from the ramus lateralis vagi, which are derived entirely from ganglion cells of the anterior component. This must mean that in this case a connexion is established secondarily between these ganglion cells and the sensory cells in the epidermis of the transplanted piece. This probably takes place in the same manner as a severed nerve grows out again to its end organ.

\section{The Regeneration of the Tail.}

For the purpose of controlling the experiments described in the second and fourth sections the normal regeneration of the tail was studied. The following account based upon this study refers almost exclusively to the regeneration of the peripheral nervous system, concerning which some new observations are recorded. These, while

pag. 373), »dass die Nerven niemals ihrem Ende zuwachsen, sondern stets mit demselben verbunden sind". Nor do the observations above described offer any evidence as to exactly how and when the connexion between nerve cell and end organ arises. They are therefore not to be construed as necessarily contradicting the view, at present almost generally accepted, that each axis cylinder grows out centrifugally from the ganglion cell to the end organ. 
snpplementing our meagre knowledge of this subject, are still of a preliminary nature ${ }^{1}$ ).

The material used consisted of larvae of R. palustris and $R$. virescens in three different stages of development. All of these are much earlier than those studied by previous writers. The youngest stage is the same as that used for the transplantation experiments (Fig. 2). The next stage is represented by larvae two days older $(6,5 \mathrm{~mm}$ long) and the third by those six days older than the first (9 mm long). On account of the absorption of the greater part of the yolk having taken place in the last named, these were found to be the most favorable for histological study, and it is upon these that the description is largely based. Serial sections, best cut parallel to the frontal plane, were found to be indispensable.

The regularity with which the tail is regenerated is remarkable although, even in outward appearance, the regenerated appendage (Fig. 2 and $4 \mathrm{Pl}$. X) never becomes exactly like the original (Fig. 1 and $3 \mathrm{Pl} . \mathrm{X}$ ). In the former the series of muscle plates does not taper quite so gradually to the end, and there is an absence of that slight thickening in the axial muscles which marks the middle region of all normal tails. Besides, the regenerated tails are much more heavily pigmented than the ones which they have replaced, and in R. virescens there are three or four blotches of black pigment arranged in a row along the lateral line which are not found in the original tails (Fig. $2 \mathrm{Pl}$. X).

The changes which mark the beginning of the rehabilitation of the peripheral nervous system of the tail, may be observed within the first twenty-four hours after amputation ${ }^{2}$ ).

In a specimen preserved eighteen hours after amputation, which is the earliest stage examined, a few fine nerve fibrils are seen to pass out from each side of the spinal cord at a point very near to the cut end. These arise from cells within the cord and have been regenerated since the operation. They are distinct from the fibres which comprise the last nerve root arising from the old part of the cord. The ganglion of this nerve was removed in the operation, but

1) FRAISSE (6) and BARFurTH (2), treating of the general subject of regeneration, devote much attention to the study of the amphibian tail. A full account here would therefore necessitate much repetition.

2) In this respect the younger larvae here studied must differ markedly from the older ones, where, according to BARFURTE, the peripheral nerves are the last structures to begin regeneration. 
the fibres of the motor root are seen to pass obliquely outwards and backwards. In later stages they mingle with the fibres regenerated from the eut end of the cord.

In a specimen preserved forty-three hours after ampatation the new nerve is very well marked, and contains a very considerable number of fibres. The spinal cord is entirely closed in and now extends $0,2 \mathrm{~mm}$ beyond the origin of the nerve, indicating new growth to that amount. At the root of the nerve and extending both proximally and distally within the substance of the cord there are situated a number of ganglion cells, which are still but slightly differentiated. It is from these cells that the nerve fibres, at least in part, arise. The new nerve is joined by a number of fibres from the next nerve root, which is the last one arising from the old part of the cord and from which the ganglion was cut off. Likewise this is connected with the last of the remaining ganglia by means of a longitudinal commissure ${ }^{1}$ ). And in this particular ease, upon which the description is based, though not in all others, an anastomosis exists between the newly regenerated nerve and the n. lateralis vagi which passes along the lateral line close by.

After the new nerve trunk is formed, as later stages show, many of the ganglion cells which were situated at the root of the nerve wander out from the cord and from a large peripheral ganglion ${ }^{2}$ ). In some cases a chain of ganglion cells extends from the last ganglion of the old part of the tail to the new ganglion, so that some of the cells of the latter may possibly be derived from the persisting ganglia. In other cases this is not true, and in all cases observed the majority of the cells of the new ganglion are traceable directly to the cord. What is more remarkable, the cells which arise from the cord seem to come rather from its ventral side, although the cord is in this region so slender that a division into the dorsal and rentral zones of Hrs can scarcely be made out. Even when the new ganglion is fully developed, a number of nerve cells still remain in the cord grouped around the point of exit of the nerve. These no doubt represent the motor elements, while those which wander out are the sensory cells.

The essentials of this new development of the peripheral nervous

1) Such longitudinal commissures connect all the nerve roots of the normal tail as was shown by Hensen (8).

2) The presence of this ganglion has been noted by BARFURTH (2, pag. 428). 
system take place within the first five days after the removal of the old appendage. At the end of this time the new nerve may be followed for some distance peripherally, where it seems to end in close proximity to the regenerating muscle cells.

In tails which have regenerated five days or more a few ganglion cells may usually be found scattered along the new peripheral nerve trunk. Later these cells segregate into several groups. In a specimen regenerated ten days two such groups of cells were found and the diminished size of the original regenerated ganglion indicated that migration of cells from there had taken place. This may be interpreted as an attempt to restore the more distally situated ganglia which were removed in amputation.

The study of much older stages shows, however, that the lost ganglia are never entirely restored. In a case where the tail had regenerated for over two months no nerve cells are to be found in the new portion of the tail beyond the original regenerated ganglion, which is situated opposite the twelfth myotome. This ganglion is large and from it several stout nerve trunks pass to the periphery, forming anastomoses with nerves arising further headwards.

In another specimen regenerated the same length of time two groups of ganglion cells were found on the regenerated nerve, and in still another, three groups of cells were present. With the exception of but one case it has not been possible to demonstrate separate dorsal roots in connexion with any of these secondary ganglia; nor as far as could be observed, do any motor roots leave the cord at any point distal to the origin of the first regenerated nerve. At least, no noticeable nerve trunks do. Nevertheless, there are a considerable number of ganglion cells and nerve fibres in the regenerated part of the cord, so that some fibres may be given off from here at intervals, perhaps singly and sporadically ${ }^{1}$.

The difference between the innervation of the normal and of the regenerated tail is, however, not so great as might be assumed from the above account, for the ganglia of the normal tail extend by $n_{0}$ means to the tip ${ }^{2}$. In $R$. palustris at least the distal half of the tail is destitute of spinal ganglia. The greater part of the tail fin is innervated by branches of the large nerve trunks which arise near

1) ef. Hensen (8).

2) This has been clearly demonstrated by Hensen (8) who has given an admirable description of the nerves of the tail. This has been snpplemented more recently from the histogenetic side by voN KöLLIKER (13). 
the root of the tail, and which, forming a plexus, give off branches to the skin and muscles of the distal part.

In the lizard, according to FraIsse, no spinal ganglia are regenerated at all after amputation of the tail, and the regenerated part of the spinal cord remains in a rudimentary condition. The new tail is innervated by three pairs of stout nerve trunks which arise from the last segment of the uninjured part of the cord. The last ganglion as well as the roots of the nerve-pair are much larger than usual ${ }^{1}$ ). In Pleurodeles the ganglia are regenerated from the ventral side of the spinal cord, while in Proteus ganglia of the tail which here extend to the tip, develop in the embryo in the same way ${ }^{2}$.

The condition found in the regenerated tails of anouran larvae (R. palustris and $R$. virescens) seems therefore, to be intermediate between the conditions found in the Lacertilia and the Urodela. As compared with the regenerated tail of the lizard, that of the tadpole more nearly attains the condition found in the normal tail.

\section{Regeneration of Reversed Tails.}

The study of regeneration shows that a lost appendage is reproduced in a manner much the same as the original mode of development. After amputation of the tadpole's tail a new one grows out which closely resembles the one cut off. The »polarity" of the organism is maintained. On the other hand, tails which have been severed from the body do not regenerate the lost trunk and head, as is true of almost any portion of such animals as planarians or hydroids, where the power of regeneration is well nigh perfect. Nevertheless, a tail removed from the body when yolk is present in its tissues, may live for ten days or more, and besides undergoing normal growt hand differentiation, may show signs of beginning regeneration headwards ${ }^{3}$ ). It might therefore be urged that non-regeneration is

1) Fratsse. 1. c. pag. 120.

2) Fraisse, 1. c. pag. 123.

3) Vurpian (25) and Born (3) have made a study of the life of such isolated tails. The latter records that both notochord and spinal cord show signs of regeneration headwards, and that they grow out to some extent into a kind of fin-fold formed by the growth of the epidermis out beyond the surface of the wound. The cut muscle fibres show signs of degeneration as is ustual before the actual regeneration begins, although in these cases the process does not pass beyond the initial stages. A full accomnt of VulPIAN's work is given by BorN (pag. 378). 
due to lack of food supply. By the method of grafting it is possible to implant an amputated tail by its distal end into the body of another larva, and thereby supply it for an indefinite period with proper nourishment, so that its eapacity of regeneration from the head-end may be tested under favorable conditions. These transplanted pieces may be placed in what might be termed the reversed natural position, that is, in place of the removed tail, or they may be grafted to any desired region of the body of another individual.

It is obvious that in the former case two like ends or "poles * are united together. The free head-end of the grafted stump is in the same position with regard to the whole organism as is the free tail-end of a larva from which the tail has been cut off. But a tail is necessary to complete the organism in the former as well as in the latter case. The question then arises, whether a tail will be produced under the influence of the position of the regenerating centre with regard to the whole organism, or whether the elements in the transplanted stump retain their original orientation and strive to reproduce the lost body ${ }^{1}$. By varying the position of the transplanted piece as mentioned above, it is possible to test the influence of functional activity upon the regenerating parts.

\section{A. Tails Grafted in Reversed Natural Position.}

Owing to the small size of the tail-bud at the grafting period it is impossible to perform directly the experiment in which the tail is reversed. The double wound which would be necessary in order to do this, is sufficient to cause the maceration of such a small piece. In order to avoid, therefore, two simultaneous cuts, the tailbuds of two larvae may be cut off and the larvae brought together end to end. After the expiration of a certain time (from one to six days) when the two individuals are firmly united and the tail stumps of each stand out more or less from the body, the two may be cut apart as shown in the sketch (Fig. 10). Thus a small part (as future development shows, portions of three or four myotomes) of the base of the tail of one larva is left attached to the tail-stump of the other, but obviously the two ends of the transplanted piece are reversed. That which was turned headwards when in connexion with its own

1) This is analogous to MoRGAN's (17) experiment with earthworms. WETzEx (27) has also recently made a similar test with hydra (see foot-note pag. 468). 
body now forms the free distal end of the tail of the new individual to which it is attached. After cutting apart, both larvae may be kept under the same conditions and observed daily in order that the regenerative process in each may be compared ${ }^{1}$ ).

This experiment was made in a large number of cases. The results were, however, in a high degree variable so that it will be necessary to describe a number of individual cases. It seems best

Fig. 10.

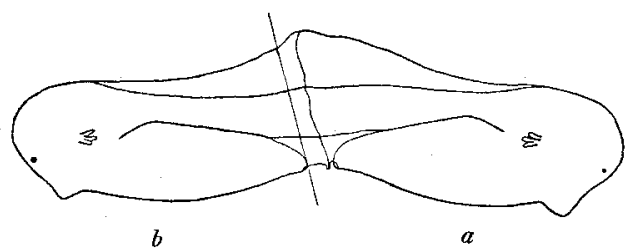

Case 1. Two days after operation, showing cut made to separate the two components. $\succ s$.

to begin with the one in which regeneration took place most regularly, that is, in a manner most like the normal regeneration from the candal end.

Case I. Both components R. virescens. Cut apart two days after union (Fig. 10). On the day after cutting, the epidermis could be seen to extend a short distance beyond the axial structures as a

Fig. 11.
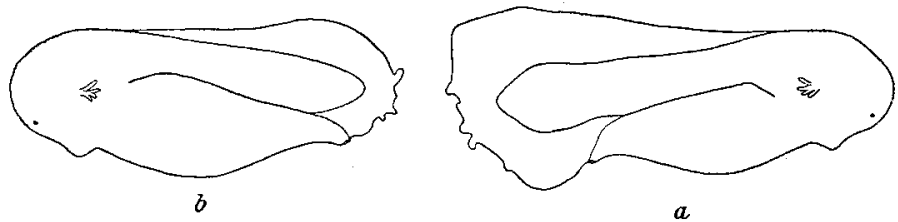

Case 1. Three days after cutting apart. $a$ combined larva; 6 accessory larva. $\times 8$.

result of the general backward shifting of the whole layer. There is a slight swelling in the axial musculature where the tissues of the two constituents adjoin. Three days after cutting the epidermis has pushed out much further, and its periphery is still rough as in the initial stages of ordinary regeneration (Fig. $11 a$ and $b$ ). The axis of

1) Of course in the strict sense this comparison should be made between regenerating grafted tails placed in normal orientation, and regenerating reversed tails, but since it can be shown that the grafted tails regenerate as readily as original tails, this precantion does not seem necessary (pag. 472). 
the tail tapers out to a point and there is already an increase of tissue at this growing end. The cells being still full of yolk granules, the larvae are so opaque that the exact lines of internal structures (myotomes, notochord, etc.) eannot be made out. Comparison of the two larvae shows similarity in the conformation of the tips of the tails.

On the sixth day enough yolk is absorbed from the tissues to render the tail more or less transparent, and now the blood may be seen for the first time circulating in the tail, in the transplanted stump as well as in the larva proper. The fin-fold has grown still further distally, and although there are still a number of surplus cells along its periphery, which give it a ragged appearance, its end is beginning to round off (Fig. 12). The transparency of the tissues now enables one to make out the contours of the muscle-plates, which are by this time distinctly $\mathrm{V}$ shaped. In those derived from the principal larva the angle of the $V$ points of course

Fig. 12.

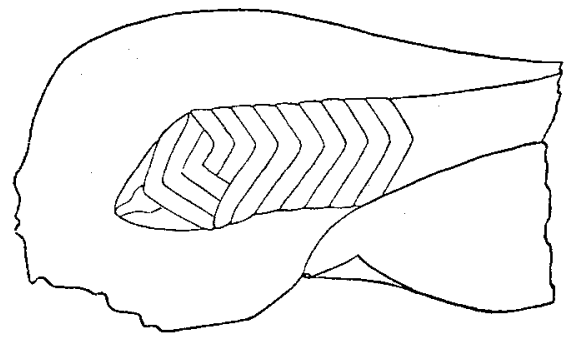

Case 1. Tail portion of combined larva (Fig.10 a) flve days after cutting apart. $\times 14$. away from the tip of the tail, but those of the transplanted piece are reversed. They are oriented just as they would have been, had they never been removed from their original position. This characteristic shape of the muscle plates had been acquired, however, before the two larvae were cut apart, to some extent even before they were stuck together. The myotomes of the two constituents are dove-tailed together. The notochord may also be clearly seen. It extends a short distance out beyond the original muscle plates. Between the latter and the tip of the notochord there are numbers of undifferentiated sarcoblasts.

On the tenth day still further advance in development is to be noted. The fin fold is now well rounded off and is beginning to become pointed as in the normal tail (Fig. 13). A slight aggregation of superfluous ectodermal cells makes a little thickening at the tip. The blood circulation is well established throughout the whole tail. The contours of the muscle plates, where the tissues of the two constituents adjoin, are about the same as they were when first noted. Measurements show that the notochord has grown $1,5 \mathrm{~mm}$ in the 
last four days. Differentiation in the regenerated portion is progressing. The more proximal of the sarcoblasts situated between the old myotomes and the tip of the notochord have given rise to muscle fibrils in which cross striation is plainly visible.

On the fifteenth day the transplanted portion of the chorda dorsalis is over four millimetres in length. The tail now tapers gradually to a point, and can scarcely be distinguished from a normal tail, except for the slight swelling of the muscle plates at the place where the two larvae were stuck together. Moreover, the creature

Fig. 13.

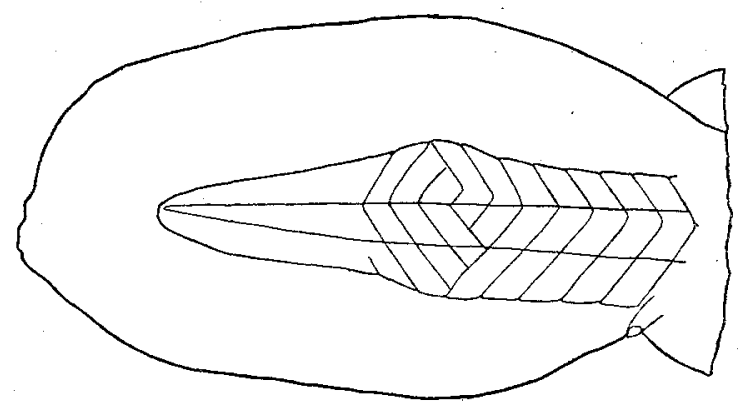

Case 1. Nine days after cutting apart. $>14$.

is now very active and swims as well and as rapidly as any other tadpole of its own size.

On the twenty-ninth day the transplanted portion of the notochord has attained a length of $7 \mathrm{~mm}$. The whole length of the organism is $17,5 \mathrm{~mm}$, of which $10 \mathrm{~mm}$ is tail. The tail of the larva with which this was united is just $10 \mathrm{~mm}$ long although the body is somewhat longer, $8 \mathrm{~mm}$. It is seen, therefore, that the normally regenerated tail has grown quite a little faster than the appendage regenerated from the head-end, for at the start the former was shorter than the latter by the length of about six myotomes. The reversed tail is slightly crooked. The tip, for instance, is bent over to the right side. This does not, however, interfere with the rapid locomotion of the animal.

This irregularity increased but little as time went on, as may be seen from comparing the two photographs (Fig. 14 and Fig. 15 Pl. X) taken respectively thirty-eight and eighty-nine days after the cutting of the larvae apart. The musculature is somewhat stonter than in an ordinary tail (Fig. 1 and $3 \mathrm{Pl}$. X) or even in a normally 
regenerated tail (Fig. 2 Pl. X). The whole appendage is not so long and the fin fold is broader and more rounded at the tip. The notochord has evidently grown more rapidly than the other structures, and hence takes a wary course from base to tip. The tail is also very heavily pigmented and although all regenerated tails of $R$. virescens are darker than the normal, none were observed so dark as this and other reversed ones. The creature has grown on the whole more slowly than the average and is inferior to its fellow in size, although it is very active and uses its tail to as much advantage as a normal individual. Stimulation of the extreme tip with the point of a sharp needle brings about the usual sudden reflex.

Fig. 14.

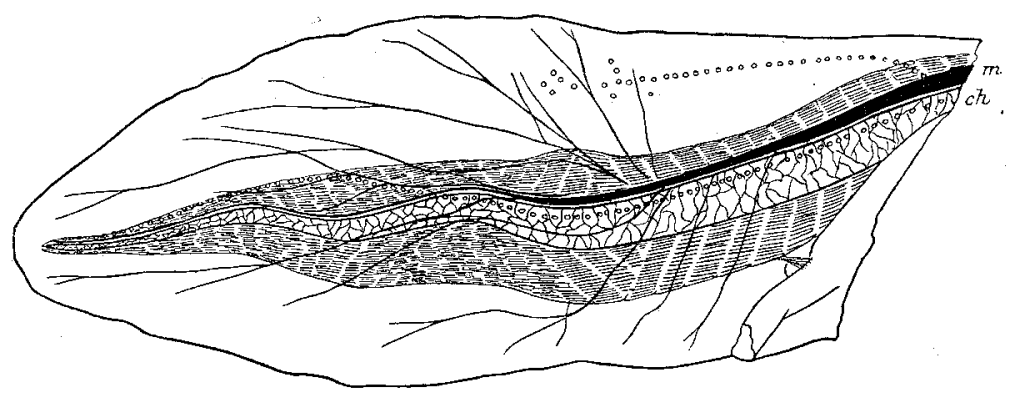

Case 1. Ninety-five days after cutting apart as seen after staining and clearing. $m$ spinal cord, ch notochord, 000 sense organs of the lateral line. $\times 6$.

A little over three months after grafting, this specimen was preserved for the purpose of more minute examination. After being stained and cleared it was first studied in toto as a transparent object, and was cut afterwards into a series of frontal sections. The main features of the tail seen as a transparent object are shown in Fig. 14. The notochord passes continuously from the region of the principal larva out into the grafted tail. An examination of the sections shows beyond doubt that the chordal tissues of the two constituents are fused completely with one another. This is unusual, and no doubt accounts for the exceptional degree of perfection attained by the regenerated tail in this individual case. The contours of the original muscle-plates, although considerably obscured by pigment, may nevertheless be traced out, and are substantially the same as when first observed. The regenerated fibres do not form very definite muscle plates, but are divided up into bundles which overlap more or less with each otber. The individual fibres are somewhat shorter 
than those at the root of the tail. A vague tendency to regular arrangement may nevertheless be made out. In the proximal part of the regenerated tail this is less apparent, but distally there is a grouping of the bundles into fairly regular segments. The contour of those quasi-myotomes tends to correspond to that of the myotomes of normal tails. They are not reversed. The spinal cord extends out to the tip of the tail and follows closely the wavy curves of the notochord. The regenerated part contains few or no ganglion cells or nerve fibres, and seems to have remained in a still more rudimentary condition than the new growth of cord in normally regenerated tails. The peripheral nerves radiate from a region in the non-regenerated part of the tail, both from the region of the larva proper and of the reversed piece. A large ganglionated plexus is situated there, the nerve cells of which are probably derived from both constituents ${ }^{1}$ ). Thence the sensory nerve fibres pass to all parts of the fin-fold (see Case 3). Those which are destined for the extreme tip of the tail pass almost longitudinally between the muscle plates of the two sides, and emerge into the fin fold well on towards their peripheral ends. One pair of nerves passes for some distance very close and parallel to the spinal cord, but in the regenerated part of the tail no nerves could with certainty be observed to arise directly from the cord.

The main series of sense organs of the lateral line has exactly the same position and distribution as usual. It extends along the side of the tail at the level of the notochord, following at first the bend of the latter. At the beginning of the distal half of the tail it passes gradually to the level of the dorsal edge of the muscle plates, along which line it extends as far as the tip of the notochord. The dorsal series of organs situated on the dorsal fin fold are not so regular and do not extend so far peripherally as is the rule. Some interruption to their normal development must have occurred.

Case 2. Both components $R$. virescens. Cut apart after being united six days. At the expiration of this time the yolk was for the greater part absorbed and the two larvae were quite active, struggling always in opposite directions. When cut apart in the same manner as in the previous case, blood streamed out from both larvae, showing that the circulation had been established from one to the other.

1) This is certainly true in a number of other cases, which were preserved and cut into sections at a much earlier stage of development. 
Regeneration took place as in the case 1 , but perhaps not quite so typically. The tail was considerably more blunt (Fig. $17 \mathrm{Pl}$. X). Functionally, however, it was a very satisfactory organ; this larva was one of the most active of those experimented upon. The arrangement of the muscle fibres and the general distribution of the peripheral nerves in the fin-fold is the same as in the first instance. This specimen was kept alive for eighty-two days. At the expiration of this time the hind leg's had developed to a considerable extent, although they were by no means so far along as is usual at the time of metamorphosis. Nevertheless, signs of degeneration were beginning to manifest themselves at the tip of the tail in the form of shriveling of the fin fold and the extremity of the axial structures (see pag. 470). The specimen was preserved before the atrophy of the grafted tissues was complete.

Case 3. In this experiment the two constituents were stuck together in the same way as before, but one of them was a palustris larva, while the other was a virescens. After being united for two days they were cut apart as shown by the line in Fig. 15, the virescens larva being left with a small portion Fig. 15. of palustris tissue attached. It

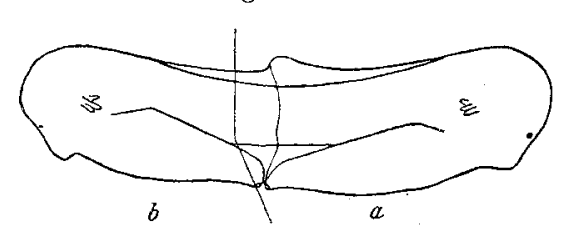

Case 3. $a$ virescens, $b$ palustris constituent. $\times 8$. will be seen that a small bit of yolk, including the anal opening, was eut off along with the tail stump. At the time of cutting the epidermis of neither larva had encroached upon the other, the pressure from each end being presumably the same. Six days after this the epidermis of the virescens was seen to extend well out over the palustris tissue dorsally. The line of demarcation (Fig. 16) between the two extended from the tip of the tail rentrally and headwards until a little below the level of the notochord where it was seen to bend ventrally. Apparently the boundary had remained nearly fixed in its ventral portion, the morement being held in check by the two anal openings (ef. pag. 441). This shifting of the epidermis in the same direction as in normal growth belps to explain the course taken by the nerves in the first case described. The arrangement of the muscle plates presented about the same peculiarity as in the former cases. The mass of grafted yolk retained its position and on the sixth day was still but little differentiated. The end-gut of the 
principal larva seems to have been fastened to that of the grafted piece, for it was pulled out horizontally beyond the usual distance. This defect was corrected as development proceeded.

This specimen continued to thrive. Fifteen days after eutting the transplanted notochord had attained the length of $3 \mathrm{~mm} .{ }^{1}$ ), the whole tail being about $5,5 \mathrm{~mm}$. long. In view of the almost perfect regeneration of this tail it is highly probable that the two notochords were entirely fused (see pag. 463). It was able to swim actively, being hindered only to a slight extent by the presence of the small mass of endoderm attached to the tail. This marked the place of union of the two constituents, and by this time was fully differentiated into a miniature coiled intestine, which was suspended by a mesentery

Fig. 16.

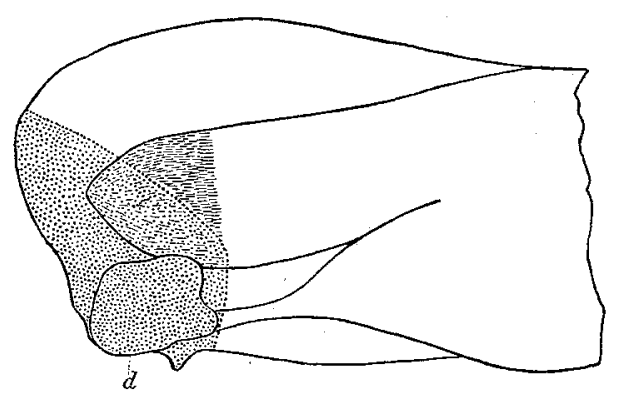

Case 3. Tail portion of virescens component (Fig. 15a) six days after cutting apart. Stippled field, palustris epidermis ; shaded field palustris musculature; $d$ palustris yolk. $>11$. in a small body carity, and could be observed to undergo continual peristaltic movement. Blood could be seen circulating freely in the walls of the intestine and mesentery. Unfortunately, this larva died shortly after these last observations were made, and was not available for histological study.

Sections were cat of several other specimens which had been treated in the same way. The intestine was found to contain a number of free cells, but of course no food matter. The anus was preserved intact and in one instance the rudiments of the hind leg's, which had been removed with the piece of yolk, could be detected. These instances indicate the high degree of specialization of the tissues at the time of grafting even though it may not be always visible to the eye (see note, pag. 465).

Case 4. In this case the two larvae, both virescens, were cut apart three days after union. At this time the epidermis covering

1) I cannot be quite sure of the exact length of this becanse the place of union could not be made out in the living specimen, although there were indications of a line at $x$ Fig. 17. 
the wound had begun to show signs of unevenness and crumpling. Two days after cutting apart a small hump made its appearance on the dorsal side of the muscle plates at the place where the two components were combined. This increased rapidly and formed a prominent projection, which on the twenty-sixth day had attained the length of $1,5 \mathrm{~mm}$. The body of the larva had then attained a length of $7 \mathrm{~mm}$ and the tail $8 \mathrm{~mm}$. The notochord of the transplanted piece was but $2,5 \mathrm{~mm}$. long as against $7 \mathrm{~mm}$. in Case 1. The external form of this specimen as it appeared forty-five days after the operation is shown in the photograph (Fig. $16 \mathrm{Pl} . \mathrm{X}$ ). After being stained and cleared

Fig. 17.

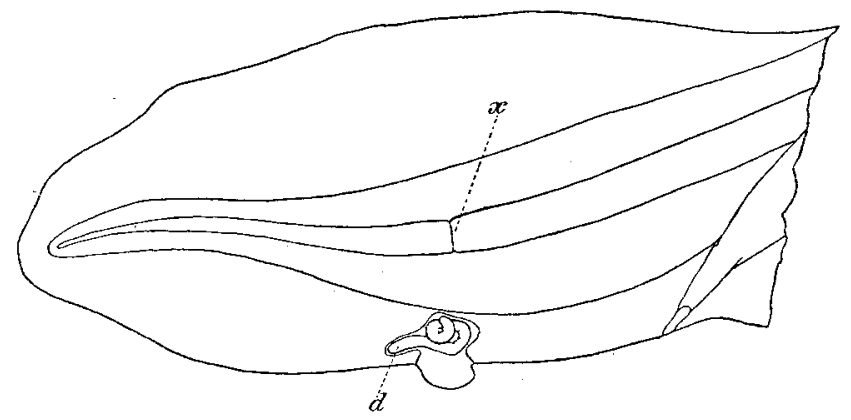

Case 3. Tail portion of $a$ (Fig. 15) fifteen days after cutting apart; $d$ intestine developed ont of grafted yolk. $\times 14$.

it was ascertained that the notochords of the two constituents had not united, but that their ends overlap somewhat and are bound together by connective tissue. At the point where the two spinal cords were joined together there is a vesicular enlargement, triangular as seen from the side in optical section. Extending from the apex of this triangle a short prolongation of the cord accompanies the dorsal prolongation of the muscle plates mentioned above. In this case the two constituents were evidently not united so exactly as in Case 1, so that the tissues of the main larva had an opportunity to grow out. Corresponding to this there was a retardation of the distal growth of the grafted piece. The forked condition of the spinal cord is, however, a rather rare occurrence, and especially so in the absence of a forked notochord.

Case 5. In this instance both constituents vere R. palustris. In preparing the larvae for grafting the tails of both were amputated obliquely, so that when stuck together the axes of the two, instead 
of being in a straight line, met at an angle of about $135^{\circ}$. The two were kept united for six days, and at the expiration of this time it could be seen that the notochord of one had regenerated ventrally, having grown out into the ventral fin fold. Accompanying this new growth of notochord were embryonic muscle cells and blood vessels, but no spinal cord. The two larvae were cut apart so that the one whose chorda was regenerating was used as the principal larva, to which the inverted tail-stump of the other was left attached. This larva had, therefore, a forked tail from the start.

Fig. 18.

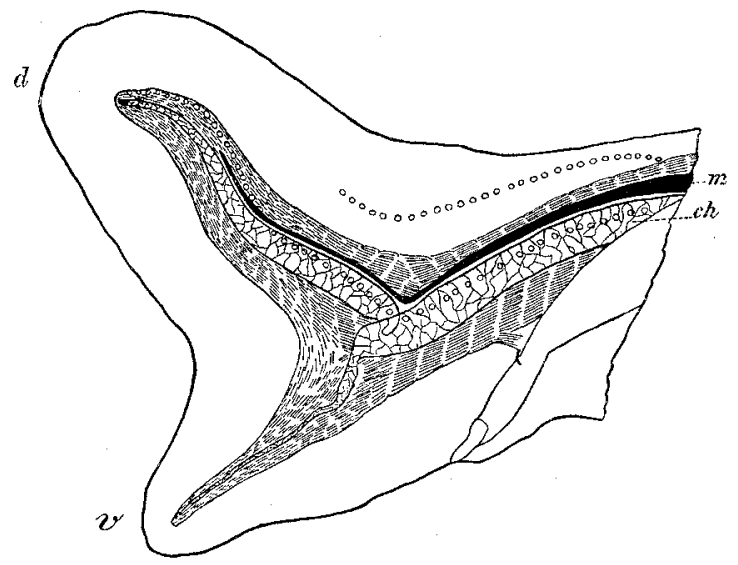

Case 5. Tail, preserved forty-five days after cutting apart. $d$ dorsal fork of tail supported by chorda of grafted piece; $v$ ventral fork of tail supported by regenerated chorda of chief component. $m$ spinal cord; ch notochord; 000 sense organs of lateral line. $\times 91 / 2$.

The upper or principal fork was constituted by the transplanted reversed tail, including its notochord, muscle plates and lastly its spinal cord, which was completely fused end to end with the spinal cord of the principal larva. The outgrowth from the tissues of the principal larva formed the ventral fork of the tail. Both of those branches grew and increased in length and so that shortly after the operation the tail bore a certain resemblance, entirely superficial of course, to the heterocercal tail of a shark (cf. Fig. 18 PI. X, which is taken from another specimen reated in exactly the same way). After forty-five days had elapsed, this specimen was preserved and studied as a transparent object (Fig. 18). The notochords had not united. The outgrowth of the chorda forming the rentral fork is of a much smaller calibre than the original part, and presents a wavy or crumpled appearance. That of the transplanted piece is almost 
normal, but is slightly wavy and ends rather bluntly. It has a length of about $4 \mathrm{~mm}$. Its proximal end is not united to the chorda of the main component, but is bent around ventrally to the side of the latter. The muscle plates are differentiated as usual. The original ones in the transplanted piece are reversed, while the newly regenerated muscles of this fork present the nsual irregularity. This is likewise true of the muscles of the ventral fork, which are undoubtedly derived from cells from both constituents. The fibres of this fork bend around and are continnous with the axial fibres both orally and caudally. The sense organs of the lateral line are continuous out along the dorsal fork, that is from one constituent to the other. The series does not divide, there being none along the ventral fork.

The forked tail in this instance was due no doubt to the fact that the notochords of the two larvae did not abut against each other, thus allowing one the freedom to regenerate. The chance to react in this way was increased by the fact that the axes of the two tails made a considerable angle with each other. This effect is not always the result of these conditions, however, and besides a forked tail may be formed when the two axes are united in a straight line. The length of time during which the two larvae were united is not a factor to be considered in this connexion, since in a majority of the cases in which the two were united for six days, simple tails resulted, and forked tails were found in several instances where the two larvae were united for but a single day. The irregularities probably arise before the two components are cut apart.

Case 6. A palustris larva was united to a virescens. The two were cut apart on the third day, leaving a small portion of the virescens attached to the palustris: A ventral outgrowth was formed, but in the present case it originated from the transplanted piece and not from the chief constituent as in the previous. The notochord bent around at almost a right angle, and embryonic musele cells derived from both constituents accompanied the growth of the chorda. The spinal cord took part likewise and became forked; this is rather exceptional. The organs of the lateral line were present in both forks. In this case, therefore, both forks were derived from the transplanted piece, and we had here the tissues of this piece growing and regenerating from both ends simultaneously, but the resultant tail was not as efficient an organ functionally as any of the cases described above. There is no essential difference in the origin of the 
irregularity in this case and in the last, for in both the regeneration had undoubtedly begun before the larvae were cut apart. The difference lies in the manner of cutting apart, but it is only in the present instance that we have one and the same notochord regenerating from both ends.

Case 7. Both constituents were R. palustris and were eut apart the day after they were united. On the twenty-third day after cutting apart the specimen was killed. At this time the tail had attained a length of $5 \mathrm{~mm}$. The regenerated part was $4 \mathrm{~mm}$ long and was regenerated from the tail of the principal larva, being very nearly straight and normal. The transplanted piece formed but an insignificant hump on the left side of the dorsal fin fold, and was attached to the muscle plates on the dorsal side. Neither the notochord nor the spinal cord was fused with the corresponding structures of the principal. No appearances of regeneration were present in either.

The following summary is an attempt to classify the various forms resulting from the same operation as described above. The frequency of each is also given.

I. Simple tails were regenerated from the cranial pole of the transplanted piece. Twenty-six instances.

a) The notochords of the two constituents were completely fused. Two instances (possibly three).

b) The notochords were partially fused. Two instances.

c) The muscle plates and spinal cords respectively, were fused, but the ends of the notochords merely abutted against each other and were united by connective tissue, the resulting regenerated tail being less perfect than in (a). Twenty-two instances.

II. Double regeneration took place, resulting in forked tails. Ten instances.

a) This was due to the regeneration of the notochord and muscle plates of the principal constituent. Five instances.

b) This was due to the growth of the tissues of the transplanted piece from both ends. Two instances.

c) Both nerve cord and notochord were forked. Two instances.

d) Nerve cord alone was forked. One instance.

III. No perceptible regeneration of any kind took place. Three instances.

IV. Regeneration took place in the tissues of the principal constituent alone. The grafted piece, which was but imperfectly 
united in the first place, remained as an insignificant mass at the side of the newly regenerated tail. Seven instances.

B. Tails Grafted to Various Parts of the Body.

Case 8. A small piece (including yolk as well as integument) was cut out of the ventro-lateral body wall of one larva, while the

Fig. 19.

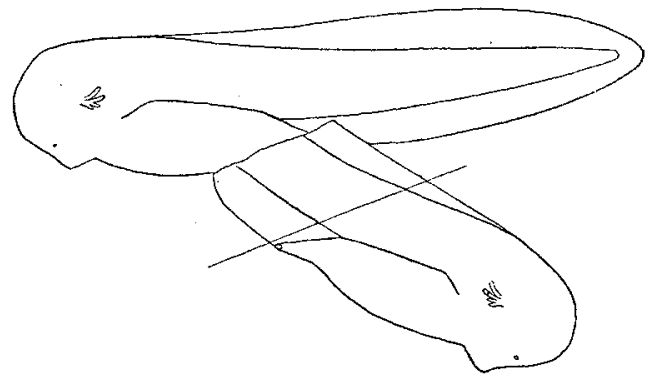

Case 8. Three days after operation showing cut made in separating the constituente. $\times 8$.

tail-bud was removed from another, and the two were stuck together by the cut surfaces. Both were larvae of $R$. palustris. They were cut apart after three days (Fig. 19). A week later the tip of the

Fig. 20.

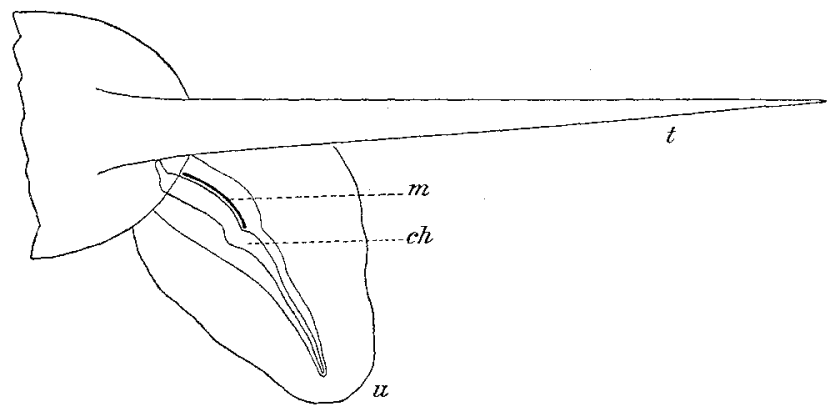

Case 8. Tail portion of Fig. 19a. Thirteen days after eutting apart. $t$ tail of principal; $u$ regenerated tail like structure; $c h$ notochord; m medullary cord. $\times 8$.

reversed tail had rounded itself off and a considerable amount of regeneration had taken place. Connexion was established with the circulatory system of the principal larva, and a lively circulation was going on in the transplanted piece. This specimen was preserved on the twentieth day after cutting. The regenerated part of the reversed tail was a little over $2 \mathrm{~mm}$. long. Both notochord and muscles with 
a well marked fin-fold had regenerated, but the spinal cord had not (Fig. 20). The mode of innervation of the grafted tissue could not be made out with certainty. Numerous sense organs, like those of the lateral line, but rudimentary and irregularly arranged, were present in the epidermis, but no nerves could be traced running to them.

Case 9. Operation was the same as in Case 8, except that the two were eut apart after one day. The regeneration was not quite so regular in this instance, and the nerve eord of the grafted tissue seems to have contracted or atrophied partially instead of having regenerated. There was of course no connexion between it and the eord of the principal larva.

Case 10. A small cut was made in the dorsal fin-fold and muscle plates of the body of one larva, extending about to the level of the spinal cord. The tail was removed from another and the two united. They were cut apart after four days, so that the reversed tail was left sticking to the back of the other larva. This grafted piece began ro regenerate from both ends, the caudal end bending: around so as to grow out freely instead of into the substance of the principal larva. Considerable growth took place from each end, but more from the oral than from the caudal (Fig. 19 Pl. X). This specimen was preserved after the expiration of four months and a half. It could be seen in the eleared object that only the muscles and notochord of the grafted tissue had regenerated. The nerve cord had not. Large cutaneous nerves extended from the principal larva out into the regenerated part of the transplanted piece.

In a few cases tail buds, not reversed, were transplanted to other parts of the body. Unfortunately, but two of these (Cases 11 and 12) were successful. In both of these the supernumerary tail was fastened in the mid-line of the back of the other larva. In both cases the supernumerary tail grew and differentiated at first, but in neither was it ever used in swimming, althongh it was sensitive to stimuli. After a time atrophy ensued in one (Case 11) and the unused appendage was partially resorbed (Fig. $22 \mathrm{Pl}$. X). In the other (Case 12) the extra tail retained its normal form much longer (Fig. $21 \mathrm{Pl}$. X), although microscopic examination of the hardened specimen (preserved three months and a half after the operation) showed that both medullary cord and muscle plates were involved in atrophy. The peripheral nerves, for the great part at least, originated from the principal larva 1 .

1) In a case which BonN described, a tail transplanted to the ventral 


\section{Discussion of the Material.}

Complete as is the union in the great majority of instances between the muscle plates and spinal cords respectively of the two components, perfect fusion of the notochordal tissues was found in but two cases, and possibly in a third. It was in these instances that the regeneration of the reversed part took place in most perfect form and almost as rapidly as regeneration from the caudal end. Where only partial fusion of the notochords occurs, which was observed in three cases, there may be considerable irregularity in regeneration. In one of these specimens there was an actual branching of the chorda to one side.

In the great majority of cases there is no actual fusion $\left.{ }^{1}\right)$. The notochords of the two components are merely bound together by their connective tissue sheaths. In many such instances regeneration from either of the approximated ends is prevented, but a new growth is provided for at the distal end of the transplanted piece, though it does not take place quite so quickly nor is it so eomplete as when the notochordal tissue of the two constituents are completely fused. The organ which results in these cases, even if the nerve cords and muscle plates respectively be united, is less perfect than the tail described in Case 1.

It often happens that the two notochords do not abut fairly against each other, or are so loosely bound together that one of them has the opportunity to regenerate. This begins before the two components are cut apart, and continues after cutting, no matter whether the regenerating chorda belongs to the main larva or to the grafted piece. Since the grafted chorda grows from its present distal end also, a forked appendage results, the two forks being usually in the same sagittal plane, at least in cases where the muscle plates are properly fused. In such cases the new outgrowth of chorda is always accompanied by muscle tissue, blood ressels and by some

body wall disappeared down to a small stump in the course of time. In my attempt to repeat this operation I was unsuccessful.

1) This has already been observed and commented upon by BorN (l. c. pag. 394), who calls attention to the relative rigidity of the chorda even in early stages, and to the fact that the cut ends often project beyond the surface of the cut, as probable factors in preventing direct union. It may also be mentioned that there is but a relatively small quantity of yolk in the notochord at this time, and that it is by far the most highly differentiated of the tissues of such young embryos. 
nerves, but usually not by the spinal cord. The two portions of the latter unite so readily and exactly, that there is but little chance for budding of the cord to take place from the region where the two components are joined. Such a bifurcation, however, occurred in some instances, three in all, and in one of which there was no forked notochord to support the secondary outgrowth. It is possible that the collection of cerebro-spinal fluid at the point where the two components are joined may give the first impulse to the outgrowth which results in the branch ${ }^{1}$ ).

If the nnion of the two components is so imperfect that neither the notochords nor the spinal cords are fused, and especially if the displacement be from side to side so that the corresponding muscle plates do not join, then the tissues of the principal larva, being free to grow, begin to regenerate rapidly and soon outstrip the feeble growth from the distal end of the transplanted piece ${ }^{2}$ ). A new complete tail is thus formed from the principal larva, the grafted piece ceases to grow and remains as a hump on the side of the new tail.

When a reversed tail is healed to another part of the body of another larva, considerable regeneration takes place in both muscles and notochord. A tail-like organ is produced with a well developed fin which is rounded at the end, but which is crumpled more or less. The spinal cord in these cases does not grow, however, and indeed it may be said that in all cases where the grafted cord remains isolated from that of the principal, it persists in a rudimentary condition or may even almost entirely degenerate.

These experiments establish beyond a doubt the fact that the regenerative power of the tissues of the tail is very considerable in both directions. The appearances of regeneration observed by

1) These cases of forked tails are analogous (the ends being reversed) to those found in some instances by JoEsT (12) when the tail pieces of two earthworms were joined together by their oral poles. In seren such cases JoEsT found that heads regenerated at the place of union. In six of these but one head was formed, while in the seventh two were regenerated (l. c. pag. 498). Similarly in Hydra, WETzEL (26) found that when two decapitated individuals were joined together by their oral ends, mouth and tentacles were formed at the place of union and the two individuals ultimately separated.

2) BoRN (1. c. pag. 396) records a case in which the muscle plates of the left side of the anterior component pass continuously into those of the right side of the posterior component. I have found several similar cases in the above series. 
Bors in the oral ends of isolated tails are the mere beginning: of what is possible provided that sufficient nutrition is supplied and functional activity afforded. That the latter is an important factor, is shown by the contrast between reversed tails implanted in the natural position and those attached to parts of the body, such as the abdominal wall, the back or the side of the tail, as in Case 7 , where they may only remain passive $\left.{ }^{1}\right)$.

In the intestine the regenerative capacity is but slight in either direction, but the power of self-differentiation is exceedingly well marked. This is shown in the persistence of small masses of endoderm which were cut off along with the reversed tail stumps in several instances. These bits of yolk not only maintain their individuality for weeks, but also differentiate into miniature intestines with mesentery, blood supply and surrounding body cavity; and this, even though functional activity is entirely excluded ${ }^{2}$ ).

As far as the histogenetic processes are concerned, there is but little difference between the mode of regeneration from the cranial and the caudal ends. For the purpose of investigating this matter a number of regenerating reversed tails were cut into serial sections.

The growth and histological differentiation of the notochord takes place just as in normal cases, beginning as a solid outgrowth of closely packed cells, which form a rod much more slender than the old chorda. Vacuolization of these cells takes place later.

The spinal cord rounds over the eut end. On the side of this, groups of ganglion cells make their appearance, and from there a pair of regenerated nerves eventually passes to the periphery. Subsequently some of the ganglion cells move out along the nerve root (see pag. 446). These processes take place considerably more slowly

1) Of interest in this connexion are the experiments of BARFurTH (1) bearing upon the functional adaptation of regenerating parts. The tails of a number of tadpoles were amputated obliquely. The axis of the regenerated tail, which is at first perpendicular to the plane of the cut, righted itself in time in all cases, but in those individuals which were permitted to swim actively this adjustment took place much more quickly than in those subjected to enforced quiet.

2) BoRN brings forward many facts which indicate the high power of self-differentiation in the tissues of frog embryos at the period when grafting is performed. He concludes (1. c. pag. 613): »Die Entwickelung entspricht also von unserem Ausgangsstadium an durchans der Mosaiktheorie Roux's; die organbildenden Keimbezirke sind ansgetheilt (HIs). * 
than when the regeneration goes on from the caudal end, and of course irregularities often arise.

The muscle fibres which were injured in entting the two larvae apart begin to break up, and traces of disintegrated fibrils may be found for four or five days. At the end oft this time a layer of embryonic muscle cells (sarcoblasts) extends from the uninjured myotomes to the tip of the newly regenerated notochord. Thus far the process is just as it takes place in ordinary regeneration. When fibrils are differentiated, however, the bundles do not become arranged into distinct muscle-plates (cf. pag. 453), but are more or less irregular (Fig. 14), while in tails regenerated from the caudal pole the arrangement of the muscle fibres assumes the same form as in the primary appendage. Obviously, there are several disturbing elements which bring the irregularity about. The muscle plates directly adjacent to the newly regenerating muscles are reversed, and their contours must have some influence upon the arrangement of the newly differentiated fibres. On the other hand, the position of the latter as regards the tail as a whole is the usnal one. The result is what might possibly be termed a compromise. The new groups of muscle fibres become arranged neither according to their original orientation nor according to their new position with respect to the whole organism. There is a tendency, however, vague as it may be, for the more distally placed fibres, that is, those considerably removed from the influences of the old muscle-plates, to be arranged into quasi-myotomes with the angle of the $V$ pointing forwards as in the usual form; but the explanation of this cannot be made clear until it is understood why the myotomes have this V-shape in all Ichthyopsida.

The question stated at the beginning of this section (pag. 449) now comes up for consideration. Are these cases to be regarded as examples of heteromorphosis or not? Especially regarding such cases as Case 1, one is at first inclined to answer this question in the affirmative. In place of a trunk and head, which have been removed, there arises a tail-like appendage, which is an organ both structurally and functionally different. Loeb's definition is apparently complied with ${ }^{1}$ ). Regeneration from the original caudal end of the tail stump was prevented by implanting that end into the tissues

1) Lows (14) who proposed the term heteromorphosis defines it (1. c. pag. 10): »Die Erscheinung, dass bei einem Thier an der Stelle eines Organs ein nach Form und Lebenserscheinungen typisch anderes Organ wächst.৫ 
of another individual. The surrounding conditions of the two ends of the grafted piece are reversed and the outcome is much the same as in the case of Tubularia ${ }^{1}$, where sticking the oral end of a bare stem into sand prevents a polyp from being formed there, while the aboral end, being free to grow, does produce a hydranth. In the case of the reversed tail the said change of surrounding conditions consists in a change of relation with regard to the rest of the organism. We would thus have a case of heteromorphosis, brought about through functional adaptation to the needs of the organism as a whole.

But on closer examination a simpler interpretation of the phenomenon becomes possible. An inquiry into the gounds for calling the regenerated appendage a tail shows that while there is a striking resemblance in external form and in the arrangement of the various component parts, this similarity may be explained by taking into account the details of the regenerative processes. The notochord is merely a straight rod, lacking visible differentiation of its elements in a cranio-caudal direction; it is therefore not remarkable that its growth, whether proceeding from one end or the other, should take place in the same manner and give the same results. Much the same might be said of the blood ressels. The spinal cord of the tail is in any case a rudimentary organ. The course of the peripheral nerves is explained by the shifting of the epidermis known to take place during development. In the only tissue in which there is normally a plainly visible orientation of the elements, viz., the axial musculature, the arrangement of the fibre bundles in the reversed tail is not as in a normal tail, either primary or regenerated, but is irregular. Moreover when it is considered that the tail of a tadpole differs from the trunk in the absence of certain characters, and only to a small extent in the presence of distinguishing ones, such as the fin folds, it becomes apparent that the taillike organ above described is not much more than what might be called an imperfectly regenerated trunk.

Thus the cases under discussion, even such as Case 1 and Case 3, lose much of their significance as examples of heteromorphosis. At most they might be regarded as heteromorphic appearances by virtue of purely negative characters, but better and simpler is it to call the phenomenon incomplete regeneration.

1) LoEB, l. c. pag. 12 . 
This interpretation is strongly supported by the second series of experiments, in which reversed tail stumps were implanted to various parts of the body (Cases 8-10). Even in these instances a by no means inconsiderable amount of regeneration occurs, and the structure produced is not unlike a tail, for it possesses all the constituents of such, including well marked fin folds ${ }^{1}$; and this takes place, although the possibility of functional adaptation to the purpose of locomotion is eliminated, and no tail is necessary to complete the organism. The effect which the position of the regenerating appendage produces is merely difference in degree of perfection. The more perfect appendage is produced when all of the constituent parts (chorda, musculature and spinal cord) of the transplanted piece are in union with the corresponding parts of the main component, i. e., are in quasi natural relations, so that they may enter upon the ordinary exercise of their function in co-ordination with the organism as a whole.

While it must be recognized, therefore, that functional activity is an important factor in regeneration, as indeed, for the ordinary welfare of a part already developed, it is of importance only to the extent that it brings about a higher degree of efficiency in a structure already capable of considerable independent development in a given direction, regardless of surrounding conditions. The present experiments do not justify us, however, in going further, in the conclusion that unusual relations imposed upon a regenerating part can call forth out of material which would normally be used otherwise, an entirely new heteromorphic structure, as a functional adaptation to new surroundings, or as the result of a striving to complete the mutilated organism ${ }^{2}$ ).

1) Only the spinal cord fails to regenerate, but this is always the case when the grafted portion fails to unite with the central nervons system of the main component.

2) Analogons experiments upon other animals give likewise no firm support to the view that heteromorphosis may be brought about through functional adaptation. MoRGax's (17) experiments upon earthworms (Allolobophora foetida) give, as far as they go, a negative answer. In the experiments in question the posterior portions of two worms were sewed together; from one of these the tail was amputated. In all cases where regeneration took place tails were formed, i. e., the part which was cut off, not the part necessary to complete the organism and render it capable of further existence.

Werzer (27) has made similar experiments upon Hydra. He united the oral portion of two polyps by the aboral end, and thus obtained a doubleheaded individnal; one head was afterwards cut off and in place of this a 
Coupled with the occurrence of heteromorphosis is the question of the polarity of the organism. Unfortunately, the term "polarity * is used with many different shades of meaning. Fundamentally, a purely geometrical conception, it signifies more when used by the morphologist, implying not only symmetry, but also an internal cause for that symmetry, by virtue of which every particle of the organism has the same polar relations as the whole. This conception is based upon facts gathered from the study of regeneration, which show that the smallest possible part of an organism capable of regeneration maintains the same orientation as the whole, from which it was cut. For example, in Hydra a head regenerates from the oral end of a fragment, and a foot from the aboral end, when the fragment is left under ordinary conditions ${ }^{1}$ ).

foot regenerated (1. c. pag. 71). This result is the opposite of Morgan's. Wetzen interprets this as a case of heteromorphosis (l. c. pag. 83), but in view of the small number of instances in which such results were observed, he is not willing to ascribe its occurrence to the influence of the uncut component upon the regenerating one. But even against regarding the case in question as heteromorphosis at all, there are objections, for it is not impossible that during the time elapsed between ampatation and regeneration, the whole of the mutilated component may have been absorbed down to the aboral end of the other component, from which, then, the foot might have been produced in the normal way (ef. NussbauM, 20, pag. 12). Unfortunately Werzen records in his paper no observations controlling this possibility. Should this objection prove to be unfounded, it still remains that the sole positive character which serves as a basis for calling the phenomenon heteromorphosis, viz., the presence of gland cells in the newly formed foot, is by no means a good criterion. The difference between the gland cells and the epithelio-muscle cells is only one of degree. Nussbaum (19, pag. 278) has shown that all of the epithelio-muscle cells contain secretory grannles, the gland cells of the foot simply containing more. And frrther, in buds transitional stages between the two kinds of cells are found at the place where the new foot is to be formed, i. e., muscle cells are here directly transformed into gland cells in the course of ordinary budding.

1) This is expressed most clearly and categorically in the oft quoted words of Nussbatu (19) as follows: $>$ Außerdem müssen wir zur Erklärtung der Erscheinungen bei unseren Versuchen noch die Annahme machen, dass die Zellen wie in den Funktionen auch in der Struktur, in dem Aufbau ihrer kleinsten Theile hoch differenzirt seien, dass nämlich innen und außen, vorn und hinten nicht allein an dem ganzen Individurm ihre volle Geltung haben, sondern dass die axialen Orientirungen des Individuums in den Orientirangen seiner kleinsten Theile begriundet seien. Es muss also in jeder Zelle ein Vorn and Hinten, ein Innen und Anßen geben, rechts und links sind dadurch von selbst bestimmt ... und da jede Zelle weiterhin theilbar gedacht werden muss, diese axiale Orientirung anch an den kleinsten Theilen der Zellen schon vorhanden sein (1. c. pag. 348). As is also seen from a later poblication, Nussbaum 20 ; intends the above to apply only to cells already differentiated. 
By imposing various external conditions upon regenerating organisms the polar relations may be modified, but it seems scarcely justifiable to conclude that such facts do away with the polarity of the organism concerned; certainly, no more so than to maintain that the fact that the poles of a magnet may be reversed by the influence of a more powerful magnetic force, does away with the polarity of the magnet.

Nevertheless, it is perhaps unfortunate that the word "polarity * should be used in connexion with the living substance, for in that case one involuntarily assumes the occurrence of phenomena of attraction and repulsion with protoplasm as the basis. At least as far as animals are concerned there is no indisputable evidence in favor of this assumption. Obviously, it may be tested best by means of grafting, whereby tissues differently oriented may be brought into organic continuity ${ }^{1}$. Even then, disturbances arising in such unions may be due to a variety of eauses, such as the reversal of structural relations upon which the exercise of normal functions are dependent ${ }^{2}$, and are not to be compared off-hand with the repulsion of like poles of magnets. Thus, the irregularities resulting in the reversed tail experiments, where two caudal poles are placed in juxtaposition, may be traced to the circumstance that two regenerative centres are brought together ${ }^{3}$.

The only phenomenon which might be interpreted as the expression of some general organic disturbance resulting from abnormal polar relations, is the degeneration which set in in some of the reversed tails, as in Case 3. Also in Case 1, where the tail regenerated

1) That the union of such differently oriented parts is easy to accomplish is manifest from all the recent experiments in the transplantation of animal tissues as is seen from the results of Bors, Wetzer, Joest, Morgan and myself.

2) This is admirably illustrated by MALL's (16) experiment in reversing a coil of intestine in the dog. The reversed coil heals perfectly with the nonreversed part, but the peristaltic movement takes place in it as if it had never been tampered with. The heaping up of the intestinal contents at the suture eventually results in the death of the animal.

3) This is in substantial agreement with WETzEL (26) who concludes from his experiments upon Hydra: „Dies dentet darauf hin, dass vielleicht weniger polare Gegensätze als überhaupt Abweichungen von der normalen Gestalt die beschriebenen Vorgänge bedingen." In his second paper WeTzeL (27) distinguishes between Regenerationspolarität « and "Verwachsungspolarität«. While these expressions do not seem to me to be quite apt, the distinction made above by me agrees essentially with WETzEL's. 
from the cranial pole was so perfect, indications of degeneration could be made out which involved both epidermis and the axial musculature. But no conclusion can be drawn from these in the absence of careful controlling experiments. Even should it turn out that the degeneration were due to abnormal postition of parts, it cannot be shown that there is any resemblance to magnetic repulsion $\left.{ }^{1}\right)$.

\section{Reactions between Tissues Derived from Different Species.}

Partly as a result of the experiments described in the second section, there were obtained a number of larvae of normal external form, but which were composed of parts derived from two distinct species. Many of these were kept under regular observation for a considerable length of time, in some cases for three or four months after the absorption of the food yolk ${ }^{2}$. The general biological interest attaching to such heteroplastic combinations is naturally great. The reactions between the tissues of distinct species, when united into one organism, deserve careful study. Unfortunately, the present material is far from adequate, but certain observations were made which seem to be of importance. These are here recorded in the hope that they may be supplemented at no late date.

First to be considered are those larvae in which the tail-bud alone was transplanted. In this combination the tissues of the one species greatly preponderate over those of the other. The grafting of the tail by itself is such a light operation (succeeding in about four cases out of five) that few abnormalities ever result therefrom.

1) Vöchting (92) on the other hand, from his elaborate study of plant grafting comes to the conclusion that the polarity of the vegetable cell is comparable to the polarity of the magnet. In the theoretical discussion of his results he states (l. c. pag. 156): »Wohl wïren wir im Stande, den Gegensatz der Pole dadurch festzustellen, dass wir die gleichnamigen und ungleichnamigen in Berührung brächten und dadurch za der Regel gelangten, dass die ersteren sich abstoßen, die letzteren sich anziehen, - ein Anziehen und Abstoßen, das sich hier freilich nicht in freien Bewegungen, wohl aber im Wachsthum äußert. Wir verführen sonach ganz wie der Physiker, der die Eigenschaften der verschiedenen Pole des Magneten auch dadurch bestimmt, dass er sie auf einander wirken lïsst.

2) Bons made extensive experiments in combining larvae of different species or even genera, as in the case of Rana esculenta and Bombinator igneus. Owing, however, to unfortunate circumstances, none of these combined specimens survived the operation mach over three weeks. 
The larvae, at least at first, are perfectly normal and are as healthy and as active as any which are born in freedom and not experimented upon. The usual development of blood vessels takes place in the tail, with the subsequent incorporation of these into the general circulatory system of the individual. The blood begins in time te flow freely from the body to the tail and back again to the body. Both parts are at first equally well nourished and grow commensurately, so that the usual aspect of the tadpole is not changed (Fig. 6 Pl. X). The body-constituent does not immediately cast off the transplanted tail and regenerate a new tail of its own species, but the latter persists even though it is of a different species, and affords a perfect substitute for the one replaced 1$)$. The tail preserves, moreover, in a general way, its specific characters even after months have elapsed, so that one who is familiar with the markings of the respective species would have no difficulty whatever in distinguishing grafted specimens from normal ones ${ }^{2}$ ).

The regenerative power of the transplanted tail is also normal as is seen from the following experiment:

Case 13. The tail of a larva of $R$. virescens was replaced by the tail of a larva of $R$. palustris, in the manner described above

1) This is different from the result which WETzeL obtained from grafting together hydras of different species (grisea and fusca). In this case, even though there be a union between the two parts, each part completes itself by regeneration of what is missing. But when the two pieces isimilarly oriented of course) are of the same species, no regeneration occurs, for then the two unite into one complete individual. WETzEL calls attention (1. c. pag. 88) to the difference between his results and BoRN's who found no regeneration from either when two pieces of different species were joined. His objection to the comparison between the resnlts in Hydra and the Amphibian embryo, viz., that in the latter searcely any regenerative capacity is present (referring of course to the trunk-region), would not hold in the case of my experiments with the tail, where the power of regeneration is very great. But then, as WETzEL points out, the union between pieces of hydras of different species is never complete and the one part does not react to stimnli applied to the other. Therein seems to lie the chief ground for the difference between his results and JoEsT's (Lumbricidae), with which latter mine agree in essentials.

2) The specific markings in later stages are due to the presence of large chromatophores, sitnated for the most part in the tissues nnderlying the epidermis. It seems certain that such cells often cross the boundary for a short distance from one species to the other, althonoth it is difficult to demonstrate this actually, sinee the markings are referable to characteristic groupings of the pigment cells rather than to differences between the individual elements of the two species. These circumstances are unfortunate for the present purpose and conspire to add a source of error in the interpretation of observations. 
(pag. 435). Forty-eight hours later, at which time the sketch (Fig. 21) was made, the tail was amputated. The epidermis from the virescens body had then pushed out considerably over the root of the tail, so that in cutting, almost all of the grafted epidermis (stippled in the figure) was removed. But a considerable portion of the underlying organs of the transplanted piece (shaded in the figure) remained, and it was from this component that regeneration took place, in all the tissues with the exception of part of the epidermis. The newly grown tail was of normal form, and as far as could be observed, it had the characteristies of the species of the grafted stump (palustris), and not those of the body (virescens) (Fig. 4 Pl. X).

\section{Fig. 21.}

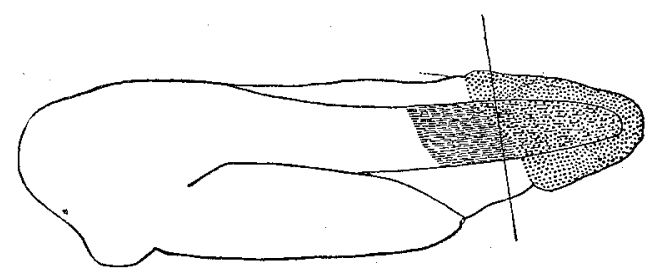

Rana virescens with tail of Rana palustris, two days after transplantation, showing place where tail was amputated. $\times 11$. For regeneration see Fig. 4 PI. $x$.

This was seen in the character of the pigmentation and especially in the absence of the Iarge black blotches along the side of the tail, which are found constantly in the regenerated appendages of $\mathbf{R}$. virescens. In spite of the insignificant size of the grafted stump as compared with the whole body, and in spite of the fact that the nourishment conveyed to the growing appendage is brought there in blood which is largely derived from the body, the tissues maintain their specifie characters 1$)$. (See foot-note pag. 476.)

A number of specimens in which each of the two components formed approximately equal parts of the individual were kept under observation. In all the cases in which this combination resulted successfully, R. virescens had been used as the head component and

1) I had hoped to obtain more definite evidence concerning the influences which regulate regeneration, from experiments carried out npon these lines. But owing to unfortunate circumstances most of the larvae of this series died. Besides, all regenerated tails deviate somewhat from the normal type, especially as regards pigmentation, which fact would bring in a considerable element of uncertainty, and in the tail I have not been able to find any other characters which could with safety be considered diagnostic of either species. 
R. palustris as the caudal. Although the reciprocal combination was tried in a considerable number of instances, for some unknown reason it never resulted in success. The palustris embryo being somewhat larger than the other, it was found advisable to cut off the head of the former in the constricted region just behind the gill arches, while the latter was cut somewhat further back where its cireumference is greater. On this account at least part of the pronephros and possibly also the rudiment of the fore leg were duplicated, but without disturbing effect.

Many of these larvae (nearly thirty) gave promise of doing well. They passed through the critical stage when the supply of food yolk is exhausted, and began to eat and to shift for themselves. All of them showed the characteristics of $R$. virescens in the head and those of R. palustris in the body and tail. However, no sharp line dividing the two constituents could be observed after the yolk and ectodermal pigment was gone (Fig. $5 \mathrm{Pl}$. X).

One by one they became weakly, decreasing considerably in size and finally dying unless preserved. Several of these larvae lived over three months; the others succumbed at various intervals.

Only one (Fig. 5 Pl. X) passed through its metamorphosis. The operation in this case was performed on April $6^{\text {th }}$. In its larval history there is nothing of individual importance to note. On August $7^{\text {th }}$, its forelegs broke through. Its metamorphosis was completed on August 10 ${ }^{\text {th }}$. The resulting frog, perfectly normal in form, was much smaller than usual, being but $1,7 \mathrm{~cm}$. $\left(\mathrm{long}^{1}\right)$. It was kept in a terrarium in which it had aceess to a pool of water. Its instincts were apparently normal, and it would spring about catching small flies and other insects, which were supplied in abundance. On August $27^{\text {th }}$ it died suddenly, death being probably due to overfeeding. The specimen was placed in formalin a few minutes after death ensued, and was afterwards photographed (Fig. $25 \mathrm{Pl}$. XI), magnified approximately two and a half diameters.

The little frog is darker than any of the specimens of either R. virescens (Fig. 23 and 24 Pl. XI) or R. palustris (Fig. $26 \mathrm{Pl}$. XI) which I have examined 2). The trunk has distinctly the markings of $R$. palustris with the dark brown squarish spots on the

1) The larvae of $\mathbf{R}$. virescens do not usually complete their metamorphosis until the following season.

2) For descriptions of these species see COPE (5). 
back arranged in two rows on a lighter field, which, in the present case, is much darker than usual. The spots are relatively larger than in the normal palustris, although I have had no specimen which was as young as this for comparison. Both pairs of legs correspond to the palustris type in the arrangement of the tubercles as well as in the markings of the skin ${ }^{1}$.

The head does not seem at first to resemble that of the normal virescens very strikingly. The snout is much too blunt and the distance between the eyes too great. These are, however, characteristics of the young individnal. The unusual protrusion of the eye-balls is a post-mortem change. There is one round spot in front of the palistris region, and this is a virescens marking, and the characteristic spot on the top of the orbit is present, though not very well defined. The lines running from the nostrils to the eye and to the shoulder are not very distinct. But what is more important than these colormarkings, the arrangement of the vomerine teeth is like that in $R$. virescens. It was observed too that, especially in the virescens part, the characteristic markings made their appearance little by little. Had the frog lived longer it does not therefore seem improbable that this part would have become more virescens-like. At any rate, the deviation of the head from the normal virescens type is not in the direction of the palustris type. And a similar statement may be made with regard to the body, for its general darkness in color can scarcely be regarded as a virescens character. Each component, then, maintains, on the whole, its own specific characters, subject, however, to certain non-specific modifications, as in the cases where the tail alone is transplanted. Of course the blood derived from the two parts is completely mixed and there is beyond doubt an interlacement of nerve fibres both in the spinal cord and peripherally. A portion of the palustris component is covered over by virescens epidermis pag. 4.41) and the virescens nerves running to this region must pass through the connective tissue of the palustris constituent. Wandering cells, pigmented and otherwise, no doubt cross the border from one component to the other. But all of these occurrences are found in the development of the normal individual, and are of the nature of the mixing of tissue-elements, rather than a blending of their

1) In grafting, the rudiment of the anterior extremity was left intact in the posterior (palustris) part, and at least part of the rudiment was left in the anterior (virescens) component. 
characters. In addition to this, the tissues of the two species undoubtedly may influence one another in various ways, as is well known in the case of plants. A discussion of these influences in the absence of more material would be premature. It will suffice here to repeat that the two components do not modify one another in the direction of their respective species ${ }^{1}$ ).

Notwithstanding the fact that the grafted appendages described in the beginning of this section are nourished and grow normally at first, their later history, as seen from the description of the following individual cases, seems to indicate that the harmony between the tissues of the two components is not permanent.

Case 14. A tail of $R$. virescens was grafted in normal position to the body of a palustris larva. The operation was performed on April $27^{\text {th }}$, the union of the parts being very exact. On. May $20^{\text {th }}$, twenty-three days later, signs of degeneration were observed in the tip of the transplanted piece ${ }^{2}$. The degeneration was at first confined to the tip, and was apparent as a slight shrinking of the tissues of the fin fold at that place, so that the distal end of the notochord projected freely beyond, as may be seen in Fig. 7 Pl. X, which is taken from case 16 . After this, atrophy proceeded very

1) This is in agreement with the conclusions reached by Vöchting (24) from a study of plant grafting. After summing up the various influences of stock upon scion he concludes (1. c. pag. 112): Zu den genannten drei Gruppen von Einflüssen würden sich, wenn ihre Existenz erwiesen wäre, als vierte die gesellen, welche als specifische unterschieden werden mögen. Das Eigenthümliche ihrer Wirkung würde darin bestehen, dass sie Veränderungen in der specifischen oder systematisch gegebenen Form hervorriefen, somit also von sehr tiefgreifender Art wären. - Derartige Einfliisse, angeblich zwar oft beobachtet, haben sich bei näherer Untersuchung in der Regel als Täuschungen erwiesen. Uns selbst ist es in keinem unserer zahlreichen Versuche gelungen, ibre Wirkung wahrzunehmen. - Durch solche Einflüsse wurden auch die sogenannten Pfropfhybriden hervorgerufen, deren Existenz aber, wie früher ausgeführt, durchans zweifelhaft ist. «

Also JoEst (12), who made numerous successful experiments in uniting earthworms of different species and genera, obtained like results. In all heteroplastic combinations each part was found to preserve its specific characters, coloration included, even down to the minutest observable details. And even in cases where one of the components regenerates a lost part, no influence upon the regenerated part could be traced to the component of the other species.

9) In the history of a composite specimen where the tail half of a larva of Rana arvalis had been transplanted to the belly of a larva of Rana esculenta, BorN mentions that the tail tip of the former showed signs of atrophy after a short time, 1. c. pag. 561. 
rapidly, although not so rapidly as during normal metamorphosis. On May $31^{\text {st }}$, eleven days after first being noticed, almost the whole of the transplanted tissue had become involved in the degeneration (Fig. 8 Pl. X). At the time degeneration began, and even after it had proceeded so far, the hind extremities were represented by the merest knob like projection on each side of the base of the tail. No metamorphosis followed the resorption of the tail. Degeneration was confined exclusively to the grafted tissue, and involved eventually the whole oft it, although it was never entirely absorbed. The larva was apparently well nourished and grew rapidly, though its appearance was rather grotesque owing to the curious shape of the remains of the tail (Fig. $9 \mathrm{Pl}$. X). On July $28^{\text {th }}$ the specimen was preserved.

Case 15. This has a history almost exactly similar to the foregoing. The atrophy of the tail was somewhat more complete (Fig. 10 Pl. X).

Case 16. The combination was the same as in the foregoing. The operation was performed on April 21 ${ }^{\text {st }}$. As in the previous cases degeneration began early, but did not proceed beyond the initial stages (Fig. 7 Pl. X) until several months had elapsed, but instead. the tail grew to an unusually great length. The grafted part, in which the blood supply was excessively rich, was distinetly marked off from the root by the smaller size of the axial musculature (Fig. $11 \mathrm{Pl}$. X). On July $26^{\text {th }}$ a sudden change was observed in the tip of the tail, which then became very deeply pigmented. Examination with the microscope showed that the blood vessels throughout the tail were distended, and that the circulation in them had practically stopped. At this time the hind legs were fairly well developed, although by no means as advanced as is usual at the time of metamorphosis. Degeneration with absorption of the tissues proceeded rapidly, but the specimen was preserved two days later before the process was completed.

Case 17. In this case the reciproeal experiment was performed. A palustris tail was transplanted to a virescens body. The grafting was done April $13^{\text {th }}$. Not until May $31^{\text {st }}$ were any signs of degeneration noted (Fig. 12 Pl. X). Atrophy of the tail proceeded with but little apparent resorption of the tissues, so that six weeks later the appearance of the larva in gross was quite different from either of the others just described (Fig. $13 \mathrm{Pl}$. X). The axis of the tail was considerably shrivelled but not much shortened. No further 
changes were noticed between July $15^{\text {th }}$, when the photograph was taken, and August $16^{\text {th }}$ when the specimen, otherwise still perfectly healthy, was preserved.

In addition to the four cases just described, there were others in which the incipient stages of atrophy were noted. Two of these were palustris larvae with virescens tails, and two were virescens larvae with palustris tails ${ }^{1}$ ).

On the other hand there were three virescens larvae with palustris tails which showed no signs of degeneration in the transplanted tissues. One of these, the case described above, in which a portion of the grafted tail was amputated and allowed to regenerate, was preserved ninety-three days after the operation, and the others, when last observed four months after, were perfectly normal.

Likewise, in some of the cases also described in the second section (pag. 440), where a small portion of the body, including some yolk, was transplanted along with the tail, similar degenerative phenomena were observed. In all, five specimens were kept for forty days or longer. Two of these, both virescens larvae with palustris tails, became weak, seemed poorly nourished, and died at the expiration of forty and sixty days respectively without showing any particular sigus of atrophy of the tail. In two others, which were otherwise apparently healthy, the tail did degenerate. The one to show it the earlier was a palustris larva with a virescens tail, in which degeneration began about the ninety-fourth day after the operation, and proceeded rapidly in much the same way as in Case 1. The other tail, which began to atrophy on the one hundred and third day, was of $R$. palustris and had been united to a virescens body. This was never absorbed as in the first case, but had an appearance much like that described in Case 16. The fifth specimen was preserved after four months, and at that time was in a perfectly healthy condition.

These cases may be summed up as follows:

Virescens tails grafted to palustris larvae always degenerate (five cases), while palustris tails grafted to virescens bodies degenerate in fifty percent (three) of the cases.

1) In three of these, degeneration was first noted after the specimens had been stained and monnted. They had lived twenty-five, twenty-one and twentyseven days respectively. In the fonrth, signs of atrophy were observed on the twenty-fourth day. A few days later this specimen died from an unknown cause. 
When a small portion of the body including yolk is transplanted with the tail, degeneration begins later than when the tail alone is remored.

Two possible causes of the premature atrophy suggest themselves. One is that it is due to the operation of grafting itself, perfect as the union of the constituents may appear $\left.{ }^{1}\right)$. The other and more probable one is that there is an incompatibility between the tissues of the two species, whereby the preponderant one poisons, or as least fails to nourish properly the other, in spite of the perfect anatomical relations ${ }^{2}$ ). In favor of this view there is some evidence, even if it is not crucial. In the first place the quantity of the tissue in the smaller constituent is an element to be considered. When part of the body along with a small portion of yolk is transplanted with the tail, degeneration does not begin until very much longer after the operation than in those cases where the tail alone is removed. This occurs in spite of the fact that the former operation involves more vital parts. In the second place, when the palustris tissue preponderates greatly over that of virescens, degeneration takes place in all cases, while in the reverse combination this degeneration does not always ensue, and when it does, it assumes a different form ${ }^{3}$ ).

The further discussion of this interesting question must be postponed until a more systematic series of experiments is made, and above all until sufficient material is at hand for a careful histological study of the degenerative processes.

\section{Summary.}

1. The embryos of Rana virescens and Rana palustris are markedly different in color. The specific coloration which is due to

1) Unfortunately, the atrophy of the tail was not observed until after the material at any disposal for experimentation was exhausted. It was, therefore, impossible to make the simple experiment of transplanting a tail from one individual to another of the same species. This would either have proved or eliminated definitely this first possibility.

2) Disharmonic combinations are well known in plants. See Vöchring (24) pag. 100. BORN (3) also touches upon this question at the conclusion of his paper.

3) Of interest in this connexion are the results obtained by L. LoEB (15) from the study of transplantation of skin in guinea-pigs. White skin transplanted to a black field behaves differently from black skin removed to a white field. The former sloughs off while the latter persists. LoEB traces this to the superior regenerative power of the dark skin. 
pigment and yolk granules is common to all cells. In heteroplastic combinations of embryos of these species, made according to Bons's method, it is therefore possible to follow in the living specimen, as development proceeds, the movement of any group or layer of cells with respect to the original dividing line between the two constitnents.

2. The combination of body and head of one species with embryonic tail bud of the other, gives the following information concerning the mode of growth of the tail: a) The epidermis passes steadily from the body to the tail, shifting over the underlying structures, so that one week after grafting, the original epidermis of the tail bud covers but about one third (the tip) of the tail. b) The musculature, spinal cord and notochord increase in length largely by apical growth, and also, but to a much less extent, by the pushing of segments (about three) out from the trunk to the base of the tail.

3 . In the trunk region, the shifting of the epidermis over the underlying organs becomes less in amount as the head is approached.

4. The movement of the epidermis is due to the tension brought about by the rapid apical growth of the tail, and the absence of a corresponding proliferating centre in the epidermis at the tip.

5. The oblique course taken by the cutaneous nerves of the trunk and tail of the full grown larva and frog, in passing from the vertebral column to their ending in the skin, is due to the ontogenetic shifting of the latter from its original position.

6. After amputation of the tail the peripheral nervous system is regenerated from the spinal cord. First a single nerve pair arises from cells lying within the cord. Part of these cells pass out upon the nerve root and from a large ganglion. Later a few of the nerve cells wander further peripherally along the new nerve trunk, forming several (at most three) ganglionic cell groups. These represent the more distally situated ganglia, lost in amputation, which are never entirely replaced.

7. The oral end of an amputated tail bud has a considerable regenerative capacity, when the bud is transplanted by its distal end to the body of another individual. The structure then regenerated is tail-like in form, no matter to what part of the body it is attached.

8. When transplanted so as to replace a normal tail the resemblance to the latter may become striking. The perfection of the part as a swimming appendage is in such cases dependent upon the exactness with which the corresponding tissues of the respective components are united. If the union is imperfect forked tails result. 
9. The cases in question are not necessarily to be regarded as heteromorphosis (tail in place of head and trunk), for the tail-like appendage is to be considered as an imperfectly regenerated trunk.

10. The position of the reversed tail stump with respect to the rest of the organism is of importance during regeneration, only in so far as it influences the degree of efficiency of the structure regenerated. Neither the present nor other experiments indicate, that the influence of the organism as a whole upon the regenerating part is able to bring forth a heteromorphic structure, functionally adapted, out of material which would normally produce something else.

11. In combinations between embryos of two species each component maintains its specific individuality. The modifications which may arise in either of the components are not of the nature of a blending of specific characters.

12. In combinations where the tail alone is replaced by a tail of the other species, the latter forms at first a perfect substitute for the original tail. Nevertheless in the majority of cases the grafted appendage atrophies later and disappears almost entirely, long before the larva undergoes its metamorphosis.

13. When a small portion of the trunk is transplanted along with the tail, atrophy of the latter is considerably delayed.

14. Also when the two components are united in the region of the pronephros, the composite larva grows normally and may remain healthy and vigorous for many weeks. Only in one case, however, did such a specimen complete its metamorphosis. The frog had perfectly normal instinets and power of co-ordination. The portions derived from each of the two species could nevertheless be distinguished clearly by means of color markings and other specific characters.

\section{Zusammenfassung,}

1. Die Embryonen von Rana virescens und Rana palnstris sind in der Farbe merklich verschieden. Die vou Pigment und Dotterkugeln abhängige specifische Färbung lässt sich in allen Zellen erkennen. Daher ist es an den nach der Bonv'schen Transplantationsmethode angefertigten heteroplastischen Vereinigungen möglich, am lebenden Thiere zu verfolgen, wie bei der fortschreitenden Entwickelung sich die verschiedenen Zellgruppen und -schichten gegen die ursprïngliche Grenzebene zwischen den beiden Theilstücken verschieben.

2. Die Vereinigung ron Kopf und Rumpf einer Art mit der embryonalen 
Schwanzknospe der anderen lüsst betreffs des Wachsthums des Schwanzes Folgendes erkennen: a) Die Epidermis rïckt stetig vom Rumpf nach dem Schwanz vor, indem sie sich über die darunterliegenden Gebilde verschiebt, so dass eine Woche nach der Verwachsung die ursprïngliche Epidermis der Schwanzknospe nur etwa ein Drittel (die Spitze) des inzwischen gewachsenen Schwanzes bedeckt. b) Die Muskulatur, das Ruickenmark und die Chorda dorsalis verlängern sich. zum größten Theil durch apicales Wachsthnm der Schwanzspitze, in geringerem Grade aber auch durch das Vorriicken von etwa drei Segmenten des Rumpftheiles.

3. Das Maß der Epidermisversehiebung am Rumpftheile ist oral am kleinsten, candal am größten; die Intensität dieser Änderung stuft sich allmählich ab.

4. Die Verlagerung der Epidermis über die darunterliegenden Gebilde ist der Spannung zuzuschreiben, die durch das rasche apicale Wachsthum des Schwanzes und das Fehlen entsprechender Vermehrungsherde in der Epidermis der Schwanzspitze verursacht ist.

5. Der schräg von der Wirbelsäule gegen die Peripherie gerichtete Verlauf der Hautnerven im Rumpf und Sehwanz der Kaulquappe und des erwachsenen Frosches kommt durch die Verlagerung der Epidermis während der Ontogenese zu Stande.

6. Nach dem Abschneiden des Schwanzes wird dessen peripheres Nervensystem vom Rückenmark aus regenerirt. Zunüchst entsteht ein einzelnes Nervenpaar ans Zellen, die im Riickenmark liegen. Ein Theil dieser Zellen schiebt sich auf die Nervenwnrzel vor, um ein großes Spinalganglion zu bilden. Nachher wandern einige Zellen noch weiter peripher dem nenen Nerven entlang und bilden ein bis drei kleine Ganglien als Ersatz für die peripher gelegenen, bei der Operation verloren gegangenen Ganglien. Letztere werden aber nie vollzählig wieder hergestellt.

7. Das orale Ende der abgeschnittenen Schwanzknospe hat ein bedentendes Regenerationsvermögen, wenn sie mit dem distalen Ende an den Körper eines anderen Individuums angeheilt wird. Das regenerirte Gebilde ist schwanzförmig, einerlei in welcher Körpergegend die Knospe angeheftet wird.

8. An einen Schwanzstummel angeheilt wird die Ähnlichkeit mit einem normalen Schwanz in manchen Fïllen auffallend. Die naturgemäße Gestaltung als Schwimmorgan hängt in solchen Fällen von der Genanigkeit a $b$, mit der die gleichen Gewebe der beiden Komponenten vereinigt sind. Ist die Vereinigung ungenau, so entsteht ein gegabelter Schwanz.

9. Diese Vorgänge sind nicht als Heteromorphose (Schwanz an Stelle eines Kopfes oder Rumpftheiles) aufznfassen, denn der schwanzförmige Anhang ist als ein unvollstïndig regenerirter Rumpf zu betrachten.

10. Die Lag*e und Orientirung des umgekehrten Schwanzstummels während der Regeneration ist nur in so fern von Wichtigkeit, als sie den Grad der Ausbildung beeinfusst. Weder die vorliegenden noch andere Versuche deuten darauf hin, dass der Einfuss des Gesammtorganismus aus dem sich regenerirenden Theil ein heteromorphisches Gebilde hervorrufen kann. Die funktionelle Ampassung wirkt somit nicht in der Richtung, dass aus einem bestimmt differenzirten Material etwas ganz Anderes entstïnde.

11. Vereinigt man Körpertheile verschiedener Species zu einem Individuum, so behauptet jeder Komponent seine specifische Individualität. Die etwaigen Veränderungen, die an den verheilten Theilstïcken anftreten, haben nicht den 
Charakter einer Bastardirung, d. h. sie erfolgen nicht in der Weise, dass die Eigenschaften des einen Theilstückes dem anderen aufgeprägt würden.

12. Wird bei derartigen Versuchen nur der Schwanz durch den einer anderen Art ersetzt, so bildet er zunächst einen vollstïndigen Ersatz für den ursprünglichen Schwanz; doch atrophirt er später und schwindet lange vor dem Beginn der Metamorphose.

13. Wo ein kleiner Theil des Rumpfes mit dem Schwanz transplantirt wird, wird das Auftreten der Atrophie verzögert.

14. Auch wenn die beiden Bestandtheile in der Vornieremregion zasammengeheilt werden, wächst die Larve wie normal und bleibt in vielen Fällen wochenlang gesund. Nur eimmal gelang es, ein derartiges Exemplar bis nach der Metamorphose am Leben zu erhalten. Der entstandene Frosch hatte durchaus normale Instinkte, Bewegung und Empfindung; doch waren die zwei zusammengeheilten Theile der beiden Species an Farbe und sonstigen specifischen Merkmalen deutlich zu unterscheiden.

\section{List of References.}

1. Barfurth, D., Versuche zur funktionellen Anpassung. Archiv f. mikr. Anatomie. Bd. 37. 1891.

2. BaRfurth, D., Zur Regeneration der Gewebe. Archiv f. mikr. Anatomie. Bd. 37. 1891.

3. Bons, G., Über Verwachsungsversuche mit Amphibienlarven. Archiv f. Entwickelungsmechanik. Bd. 4. 1896/\%.

4. Byrnes, E. F., Experimental Studies on the Development of Limb-Museles in Amphibia. Jonrn. of Morphol. Vol. 14. 1898.

5. Cope, E. D., The Batrachia of North America. Bulletin of the United States National Musenm. No. 34. 1889.

6. Fraisse, P., Die Regeneration von Geweben und Organen bei den Wirbelthieren, besonders Amphibien nnd Reptilien. Kassel und Berlin 1885.

7. Head, H, On Disturbances of Sensation with Especial Reference to the Pain of Visceral Disease. Brain. Vol. 16. 1893.

8. Hensen, V., Über die Nerven im Schwanz der Froschlarve. Archiv f. mikr. Anatomie. Bd. 4. 1868.

9. HeNsen, V., Beobachtungen über die Befruchtung und Entwickelung des Kaninchens und Meerschweinchens. Zeitschr. f. Anatomie r. Entwickelung:sgeschichte. Bd. 1. 1876.

10. Hertwig, O., Beiträge zar experimentellen Morphologie und Entwickelungsgeschichte. I. Die Eatwickelung des Froseheies unter dem Einfluss schwächerer und stärkerer Kochsalzlösungen. Archiv f. mikr. Anatomie. Bd. 44. 1895.

11. Hoen, A. G., The Photographic Room and Apparatus in the Anatomical Laboratory of the Johns Hopkins University. Bulletin of the Johns Hopkins Hospital. Vol. 7. 1896.

12. Joest, E., Transplantationsversuche an Lumbriciden. Morphologie n. Physiologie der Transplantationen. Archiv. f. Entwickelungsmech. Bd. 5. 1897.

13. v. KöLLIKER, A., Histologische Untersuchungen an Batrachierlarven. Zeitschrift f. wiss. Zoologie. Bd. 43. 1886. 
14. LokB, J., Untersuchangen zur physiologischen Morphologie der Thiere. I. Über Heteromorphose. Würzburg 1891.

15. Lows, L., Über Transplantation von weißer Hant auf einen Defekt in schwarzer Hant und umgekehrt am $\mathrm{Ohr}$ des Meerschweinchens. Archiv f. Entwickelungsmechanik. Bd. 6. 1897.

16. Mall, F. P., Reversal of the Intestine. Johns Hopkins Hospital Reports. Vol. 1. 1896. Paper dated Dec. 1889.

17. MorgaN, T. H., Regeneration in Allolobophora foetida. Archiv f. Entwiekelungsmechanik. Bd. 5. 1897.

18. Morgan, T. H., and Tsuda, U., The Orientation of the Frog's Egg. Quart. Journ. Micr. Science. Vol. 35. 1894.

19. Nussbaum, M., Über die Theilbarkeit der lebendigen Materie. II. Mittheilung. Beiträge zur Naturgeschichte des Genus Hydra. Archiv f. mikr. Anatomie. Bd. 29. 1887.

20. Nussbaum, M., Die mit der Entwickelung fortschreitende Differenzirung der Zellen. Sitzungsber. d. Niederrhein. Geselisch. f. Natur- u. Heilkunde zu Bonn. 1894. Reprinted in Biolog. Centralbl. 1895.

21. Peters, A., Über die Regeneration des Epithels der Cornea. Inaug.-Diss. Bonn 1885.

22. Sherrngtron, C. S., Experiments in Examination of the Peripheral Distribution of the Fibres of the Posterior Roots of some Spinal Nerves. Philosophical Transactions Roy. Soc. London. Vol. 184. 1893.

23. Virchow, H., Die Schwanzbildung bei Selachiern. Sitzungsber. d. Gesellsch. naturforseh. Freunde in Berlin. 1895.

24. VöснтікG, H., Über Transplantation am Pflanzenkörper. Untersuchnngen zur Physiologie und Pathologie. Tübingen 1892.

25. Vulpian, M. A., Notes sur les phénomènes de développement qui se manifestent dans la queue de très jeunes embryons de grenouille, après qu'on l'a séparée du corps par une section transversale. Comptes Rendus de l'Académie des sciences. Tome 48. 1859. (Cited according to BonN.)

26. Wetzer, G., Transplantationsversuche mit Hydra. Arehiv f. mikr. Anatomie. Bd. 45. 1895.

27. Wetzer, G., Transplantationsversuche mit Hydra. Archiv f. mikr. Anatomie. Bd. 52. 1898.

28. Wirsox, C. B., Experiments on the Early Development of the Amphibian Embryo, under the Influence of RIVGER and Salt Solutions. Archiv f. Entwickelungsmeohanik. Bd. 5. 1897.

\section{Explanation of Plates.}

Plate X.

(All photographs taken from the living tadpoles.)

Fig. 1. Rana virescens, normal with the exception of the tip of the tail, which is regenerated. $\times 2$.

Fig. 2. Rana virescens, with regenerated tail. $\times 31 / 3$. Note deepness of pigmentation of the tail, especially the large blotches.

Fig. 3. Rana palnstris, normal. $\times 2$. 
Fig. 4. Case 13. Rana virescens, with tail of Rana palustris, which is for the greater part newly regenerated. $\times 3$.

Fig. 5. Head of larva (inclnding gills) Rana virescens, remainder Rana palustris. Photograph taken one hundred days after operation. $\chi 2$. Same individual as frog (Fig. 25).

Fig. 6. Rana palustris, with tail of Rana virescens. Twenty-seven days after operation. Scarcely perceptible signs of atrophy in tail tip. $\times 31 / 3$.

Fig. 7. Case 16. Same combination as Fig. 6. Forty days after operation Tip of fin fold has atrophied. $\times 3 \frac{1}{3}$.

Fig. 8. Case 14. Same combination as Fig. 6. Thirty-five days after operation. Degeneration of transplanted tail, much further advanced than in Fig. 7. $\times 31 / 3$.

Fig. 9. Case 14. Seventy-seven days after operation. $\times 21 / 2$.

Fig. 10. Case 15. Same combination as the foregoing. Eighty-one days after operation. $\times 2$.

Fig. 11. Case 16. Eighty-three days after operation. $\times 21 / 2$.

Fig. 12. Case 17. Rana virescens with tail of Rana palustris. Forty-eight days after operation (cf. Fig. 7). $\times 31 / 3$.

Fig. 13. Case 17. Ninety-three days after operation. $\times 3$.

Fig. 14. Case 1. Rana virescens with regenerated reversed tail of another individual. Regenerated thirty-eight days. $\times 31 / 3$.

Fig. 15. Case 1. Regenerated eighty-nine days. $>3$.

Fig. 16. Case 4. Same combination as Fig. 14. Tail regenerated forty-two days. Forked spinal cord. $\times 31 / 3$.

Fig. 17. Case 2. Same combination as in Fig. 14. Regenerated thirty-seven days. $\times 31 / 3$.

Fig. 18. Case 5. Combination as in Fig. 14 except that both larvae are Rana palustris. Tail regenerated sixteen days. $\times 33^{1 / 2}$.

Fig. 19. Case 10. Rana palustris with reversed tail of another larva grafted to its back. The transplanted tail has regenerated from both ends (twentytwo days). $\times 31 / 3$.

Fig. 20. Same combination as in Fig. 19 except that a small portion of yolk was transplanted with the tail. Regenerated sixteen days. $\times 31 / 3$.

Fig. 21. Case 12. Rana palustris with accessory tail grafted to the back. Twenty-one days after operation. $\times 3 \frac{1}{3}$.

Fig. 22. Case 11. Same combination as in Fig. 21. Sixty-nine days after operation. Accessory tail to a great extent atrophied. $\times 21 / 2$.

\section{Plate XI.}

(All specimens preserved in formalin.)

Fig. 23. Rana virescens, adult female just after spawning. $x^{4 / 5}$.

Fig. 24. Rana virescens, adult male. $\times 4 / 5$.

Fig. 25. Same individual as in Fig. 5. Head, Rana virescens; trunk and limbs, Rana paltustris. Preserved one hundred and forty-three days after operation, or seventeen days after metamorphosis. $\times 21 / 3$.

Fig. 26. Rana palustris, young specimen. $\times 4 / 5$. 